\title{
RESPONSABILIDADE PÚBLICA POR ATIVIDADE JUDICIÁRIA NO DIREITO BRASILEIRO
}

\author{
LAIR DA SILVA LOUREIRO FILHO*
}

SUMÁRIO: 1. Da responsabilidade pública no Brasil; 1.1 Consideraçōes gerais: 1.2 Evolução histórica: I.3 A responsabilidade objetiva da regra constitucional. $O$ art. $37, \$ 6^{\circ}$ e seu alcance - 2. Responsabilidade pública por atividade judiciária no direito brasileiro; 2.1 Espécies de responsabilidades do juiz; 2.I.I Responsabilidade política; 2.1.2 Responsabilidade social; 2.1.3 Responsabilidade juridica; 2.2 Evolução histórica do instituto no direito positivo brasileiro; 2.3 Do sistema no direito positivo contemporâneo; 2.3.1 Da tutela constitucional e seus efeitos; 2.3 .2 Código de processo penal; 2.3.3 Código civil de 1916; 2.3.4 Código de processo civil; 2.3.5 Lei orgânica magistratura nacional - 3. Conclusões.

Palavras-chaves: Responsabilidade pública - Responsabilidade civil do Estado - Poder Judiciário - Atividade judiciária - Magistratura - Erro judiciário.

Resumo: Um dos fundamentos do Estado do Direito está na responsabilidade pública plena, por danos causados em razão do desempenho de suas atividades. A unidade da soberania estatal enseja a de sua responsabilidade, sendo irrelevante se o ato lesivo resulta de atividade do Executivo, Legislativo ou Judiciário. A doutrina e jurisprudência contemporâneas caminham a passos lentos nesse sentido. $O$ direito brasileiro, a exemplo do estrangeiro (analisados neste trabalho o inglês, francês e espanhol), ainda reluta em estender à atividade do Poder Judiciário as consequiências da responsabilidade pública em geral.

No Brasil, o acesso à prestação jurisdicional constitui direito fundamental (assegurado pelo art. $5^{\circ}, \mathrm{XXXV}$ da Constituição), sendo garantida a apreciação pelo Poder Judiciário de lesão ou ameaça a direito individual, difuso e coletivo. Tal

* Mestre em Direito do Estado pela USP; Especialista em Direito Constitucional Comparado Samford/EUA: Professor dos Cursos de Pós-Graduação do UniFMU e Mackenzie; Professor dos Cursos de Graduação no UnifMU e UNIP: Membro do Instituto dos Advogados de São Paulo

\begin{tabular}{lll}
\hline R. Dir. Adm., & Rio de Janeiro, 231: 5-46, & Jan./Mar. 2003 \\
\hline
\end{tabular}


dispositivo, contudo, vem sendo sistematicamente violado quando não ignorado pela ineficiente atividade judiciária desenvolvida neste país, bem como pela excessiva demora na prestação jurisdicional.

Nesse sentido, o direito brasileiro contemporâneo disciplina o instituto de forma dispersa e por vezes antinômicas, a contar da nebulosa constitucionalidade do art. 133 do CPC (dolo, fraude e desídia do juiz) repetido pela LOMAN, e do cipoal formado pelo art. 630 da lei adjetiva penal (erro judiciário ao qual se contrapôe o abrangente art. $5^{\circ}, \mathrm{LXXV}$ da CF), e mesmo do Codigo Civil (hipóteses subjetivas dos arts. 294, 420 e 421 e objetiva do revogado art. 15), instituídos muito antes da previsão do art. $37, \S 6^{\circ}$ da Constituição. em face da qual os dispositivos devem ser confrontados.

A regra geral do art. $37, \S 6^{\circ}$, outrossim, abrange todas as demais hipóteses de maneira clara, bastando a constatação da existência de liame entre a conduta do agente (sob qualquer vínculo com a administração), lícita ou ilícita, e o dano injustamente sofrido pelo usuário da atividade judiciária (consideradas por certo as suas excludentes), objetivando amplo e propocional ressarcimento da mesma forma que efetivo desestímulo à conduta sancionada.

A conjugação de ambos os regimes, o da responsabilidade pessoal do juiz (abdicando o autor dos privilégios da solvência dos cofres públicos e da inversão do ônus da prova) e o da responsabilidade objetiva do Estado coexistem em prol do usuário da atividade a quem caberá a escolha em face de quem demandar e a qual título.

\section{I - Da responsabilidade pública no Brasil}

\section{1 - Considerações Gerais}

O sistema Brasileiro alcançou a fase mais avançada da responsabilidade pública acerca de meia centúria, ao adotar a teoria objetiva (expressamente em 1946), prescindindo do elemento culpa a relação entre Administração e administrado, restando a discussão desta à alçada regressiva perante o agente faltoso. Ademais, só com a Carta de 1988 é que se passa a denotar sentido amplo ao utilizar a expressão agente e não mais funcionário, equiparando, ainda as pessoas jurídicas de direito privado quanto à vinculação imperativa da responsabilidade pública.

Nesse diapasão, a individualização da culpa ou do dolo do agente público interessa apenas para fins de regresso. sem que afete a responsabilidade objetiva do Estado perante terceiro prejudicado. Duas relações distintas, portanto, são estabelecidas entre diferentes sujeitos, com fundamentos diferentes: uma de natureza objetiva, fundada no risco, entre a Administração e o administrado lesado, outra de cunho subjetivo, fundada na culpa, entre o Estado e seu agente faltoso (se houver culpa e se possível a identificação ou mesmo existente o agente).'

1 Esclarecedora, nesse sentido, a liçĩo de Weida Zancaner, em referência ao art. 107 da Constituição de 1969. "Límpida é a letra da lei, sem meandros. incisiva mesmo, a nosso ver. Não há que 
O consenso sobre a adoção da responsabilidade objetiva pelo texto constitucional, contudo, não se repete quanto à extensão do conceito de responsabilidade objetiva, conforme visto, exatamente em função da teoria que deve servir-lhe de fundamento (risco: integral, proveito ou administrativo).

Sistema bem positivado no ordenamento carece, contudo, de uma dinâmica que somente uma reforma judiciária estrutural poderia trazer, sem levar-se a problemática a questões macroestruturais da realidade econômica, social e política brasileira. Apesar do direito objetivo prever um instituto bem posto, hábil em garantir o direito subjetivo do administrado lesado, restam alguns pontos nada desprezíveis, diga-se, como a eficácia na execução das condenações, assim como a longa espera pelo pagamento dos precatórios; mas essa é outra história.

A visão histórica evolutiva da responsabilidade pública, bem como suas manifestações características no direito estrangeiro apontam, e delimitam, sua compreensão na realidade brasileira. O período colonial é marcado pela irresponsabilidade do Estado. A partir do império percebem-se diplomas que prevêm, ainda que de forma isolada e pontual, o nascimento deste instituto no ordenamento brasileiro. Com a era republicana, temos o reconhecimento definitivo e explícito do instituto, ainda de perfil civilista, a teor do disposto no art. 15 do Código Civil de 1916.

A previsão da responsabilidade pública como regramento constitucional surge nas constituições deste século, notadamente nas de 1934 e 1946, ora ampliando ora restringindo o alcance do tex to quanto ao responsável pela causação do dano (pessoa jurídica de direito público ou pessoa jurídica de direito privado prestadora de serviço público), quanto à extensão da conceituação de funcionário à de agente (o que inclui todos aqueles que praticam atos a serviço do Estado), quanto ao exercício, pelo Estado, do direito ou da ação regressiva àquele subjetivamente responsável pelo dano experimentado pelo particular. Enfim, a construção hermenêutico-jurisprudencial de um instituto que, em princípio e em linhas gerais, encontrou adequada e precisa previsão na regra do art. $37, \S 6^{\circ}$ da Carta de 1988 , compatibilizando verdadeira concomitância das teorias objetiva (Estado/vítima) e subjetiva (Estado/Agente), já presente na Carta de 1967, diga-se.

\section{2 - Evolução Histórica}

No Brasil Colônia dominou, de modo incontestável, a idéia da plena irresponsabilidade do Estado. Com a independência, muda-se a situação e passa-se a admitir que o Estado seja responsável pelos atos ou omissões ilícitas de seus agentes.

falar ter a Constituição acolhido a teoria subjetiva, nem sequer pode-se dizer que a teoria objetiva seja a única abrangida pelo art. 107. Há concomitância de teorias, as duas acolhidas pela letra da lei, mas prepondera um divisor de águas: a teoria objetiva tem seu lugar nas relações entre o administrado e o Estado, restando à teoria subjetiva os casos preceituados no art. 107, parágrafo único, que regula as relações Estado-funcionário" (Da responsabilidade extracontratual da Administração Pública, p. 61). 
A Constituição Imperial de 1824, em seu art. 179, inc. 29 ("os empregados públicos são estritamente responsáveis pelos abusos e omissões praticados no exercício de suas funções, e por não fazerem efetivamente responsáveis aos seus subalternos") cuida apenas da responsabilidade pessoal dos agentes públicos.

A Constituição Republicana de 1891, em seu art. 82 ("os funcionários públicos são estritamente responsáveis pelos abusos e omissões em que incorrerem no exercício de seus cargos, assim como pela indulgência ou negligência em não responsabilizarem efetivamente aos seus subalternos"), reproduz sem inovações o instituto tal qual fora previsto na Carta anterior.

Até então, não se tratou expressamente da responsabilidade pública, restando a tutela do dano injusto circunscrita à responsabilização pessoal do agente faltoso, sob a competência federal. Nesse sentido, a lição de ODETE MEDAUAR", "As Constituições de 1824 e de 1891 não cuidaram da responsabilidade civil do Estado. A lei 221, de1894, atribuiu aos juízes e tribunais federais o julgamento das causas relativas à lesão dos direitos individuais por decisões das autoridades administrativas da União".

Pontuam entendimento diverso, embora não tão distante, aqueles que enxergam, nos textos de 1824 e de 1891, a solidariedade do Estado na disciplina da responsabilização pessoal dos funcionários públicos. ${ }^{3}$

Ademais, um sem número de leis esparsas do século XIX dispunham sobre a responsabilidade pública, conforme elenca AMARO CAVALCANTI ${ }^{4}$, tais como o Decreto 1.930, de 26.4.1857, relativo aos danos causados por estrada de ferro; o Decreto 9.417, de 25.4.1885, também interessante à matéria; o Decreto 1.663 , de 30.1.1894, art. 552, o Decreto 4.053, de 24.6.1891, art. 538, concernentes à indenização por prejuízos decorrentes de colocação de linhas telegráficas; os Decretos 1.692-A, de 10.4.1894, art. $8^{\circ}$. e 2.230. de 10.2.1896, art. $6^{\circ}$, que cuidam da responsabilidade da União ligada aos serviços de correios, e muitos outros ${ }^{5}$.

Antes do art. 15 do Código Civil de $1916^{6}$, a Constituição Republicana e a Lei 221 , de 1894, como visto, regulamentavam, ainda que de forma indireta. a responsabilidade pública. Destarte, foi o texto civilista o primeiro a prever a responsabilização do Estado.

2 Direito administrativo moderno, p. 431.

3 A esse propósito a lição de Celso Antônio Bandeira de Mello, para quem, "Ditos preceptivos. todavia, jamais foram considerados como excludentes da responsabilidade do Estado e consagradores apenas de responsabilidade pessoal do agente. Pelo contrário: entendia-se haver solidariedade do Estado cm relação aos atos de seus agentes" (Curso de direito administrativo, p. 685).

4 Responsabilidade civil do Estado, vol. II. p. 612-618.

5 José Cretella Júnior acrescenta outros textos conformando extenso rol legislativo (Tratado de Direito Administrativo, p. 169).

6 É o teor do art. 15 do Código Civil de 1916, in vebis: "as pessoas jurídicas de direito público são civilmente responsáveis por atos de seus representantes que, nessa qualidade, causem danos a terceiros, procedendo de modo contrúrio ao direito ou faltando a dever prescrito por lei, salvo o direito regressivo contra os causadores de dano". 
O texto civilista não refletiu a tendência dos tribunais cuja jurisprudência dominante abria espaço à responsabilidade extracontratual do Estado, então caracterizada como responsabilidade civil, eis que inteiramente insculpida sobre o desenho do Direito Privado, no que pese alguns autores enxergarem remissão, ainda que tênue, à doutrina objetiva.

A disciplina privatista do instituto de Direito Público no Código Civil, reflete o contexto em que foi elaborado impregnado de forte teor individualista (exatamente o que se pretende mudar com a reforma do novo - e já não tão novo assim Código) havendo que se questionar se a redação ambigua do seu art. 15 estaria a ensejar alguma concessão à responsabilidade objetiva, a exemplo da inspiração Francesa (teoria do risco) na passagem do século. Pouco provável.

Vale a pena, a esse propósito, citar o elastério do professor Almiro do Couto e Silva", "Seja como for, o certo é que o art. 15 do CC cogitou apenas da responsabilidade do Estado por atos ilícitos, não abrangendo, pois a que resulta de atos lícitos. Contribuiu decisivamente, desse modo, para fracionar a noção geral do dever de indenizar do Estado, rumo que era preconizado pela doutrina italiana ao fazer a bem conhecida distinção entre reparação por atos lícitos e ilícitos e ao designar a primeira como ressarcimento e a segunda como indenização".

Prossegue o mestre gaúcho, com meridiana clareza, "Observe-se que na primeira obra brasileira de relevo sobre a responsabilidade extracontratual do Estado, escrita antes do Código Civil (Amaro Cavalcanti), o dever de indenizar do Estado era tratado unitariamente, compreendendo a responsabilidade tanto por atos lícitos como por atos ilícitos. Rui Barbosa, aliás, já pensava assim. $\mathrm{O}$ art. 15 do $\mathrm{CC}$ e a influência que, após, exerceu a obra de Alessi afastaram a maior parte da doutrina nacional dessa orientação, agrupando as diferentes espécies de intervenções lícitas do Poder Público na propriedade dos administrados ou em torno da noção de poder de polícia, ou do instituto da desapropriação. Este último chegou até mesmo a abarcar uma forma de intervenção ilícita, a chamada desapropriação indireta".

O Decreto n. 24.216, editado em 09.05.1934, em manifesto intento de beneficiar o erário, entra em vigor pouco antes da Constituição de 1934 (promulgada em 16 de junho), excluiu a responsabilidade do Estado por atos criminosos de seus agentes em seu art. $1^{\circ}$ ("a responsabilidade civil da União pelos atos criminosos de seus representantes, funcionários ou prepostos, ainda quando praticados no exercício do cargo, função ou desempenho de seus serviços, salvo se nêle forem mantidos após sua verificação"). Odioso dispositivo restou, afinal, revogado pelo artigo 171 da Carta ditatorial de 1937.

7 A responsabilidade extracontratual do Estdo no direito brasileiro, p. 21-22. 
A Constituição de 1934 , em seu art. $171^{8}$, foi a primeira a conter dispositivo expresso sobre a responsabilidade extracontratual do Estado criando o regime da responsabilidade solidária entre o agente público e o Estado, mantendo o regime de responsabilidade do Estado por atos ilícitos.

A carta de 1937 mantém o teor da Constituição anterior no que diz respeito à responsabilidade estatal, em seu art. $158^{\circ}$.

A Constituição de 1946 , em seu art. $194^{10}$, elimina a culpa do conceito, adotando a teoria objetiva. Apenas com a Constituição de 1946 ocorre a adoção expressa da responsabilidade objetiva do Estado. O elemento culpa é previsto, tão-só, para assegurar a ação regressiva das pessoas jurídicas contra os funcionários causadores do dano quando tiver havido dolo ou culpa deles, devendo as entidades reparar o dano mesmo sem a ocorrência de culpa. Rejeitada, ademais, a solidariedade entre Estado e funcionário, restando tal vínculo a ser resolvido perante a via regressiva.

A Constituição de 1967 , em seu art. $105^{11}$, mantém a mesma abordagem do tema, incluindo, sem necessidade é bem verdade, o dolo ao lado da culpa, como pressuposto da ação de regresso.

A Emenda Constitucional $\mathrm{n}^{\circ} 1$, de 1969 , em seu art. $107^{12}$, apenas repete o texto anterior.

Mantendo os mesmos princípios, a "Constituição Cidadã" de 1988 (art. 37, § $6^{\circ}$ ) ampliou a extensão dessa responsabilidade como será visto adiante.

\section{3 - A Responsabilidade Objetiva da Regra Constitucional - $O$ art. 37. $\$ 6^{\circ} \mathrm{e}$ seu alcance}

Preceitua o art. 37, $\S 6^{\circ}$ da Constituição Federal, “As pessoas jurídicas de direito público e as de direito privado prestadoras de serviços públicos responderão pelos danos que seus agentes, nessa qualidade, causarem a terceiros, assegurado o direito de regresso contra o responsável nos casos de dolo ou culpa".

8 in verbis. "Os funcionários públicos são responsáveis solidariamente com a Fazenda Nacional, Estadual ou Municipal, pôr quaesquer prejuizos decorrentes de negligencia, omissão ou abuso no exercício dos seus cargos; $\$ 1^{\circ}-\mathrm{Na}$ acção proposta contra a Fazenda Pública e fundada em lesão praticada pôr funccionario, este será sempre citado como litisconsorte: $\$ 2^{\circ}$ - Executada a sentença contra a Fazenda, esta promoverá execução contra o funccionario culpado".

9 In verbis: "Os funcionários públicos são responsáveis solidariamente com a Fazenda Nacional, Estadual ou Municipal pôr quaisquer prejuízos decorrentes de negligência, omissāo ou abuso no exercício dos seus cargos".

10 In verbis: "As pessoas jurídicas de direito público interno são civilmente responsáveis pelos danos que os seus funcionários, nessa qualidade, causem a terceiros; parágrafo único - CaberIhes-à ação regressiva contra os funcionários causadores do dano quando tiver havido culpa destes". 11 In verbis: "As pessoas jurídicas de direito público respondem pelos danos que os seus funcionários, nessa qualidade, causem a terceiros: parágrafo único - Caberá ação regressiva contra o funcionário responsável, nos casos de culpa ou dolo".

12 In verbis: "As pessoas jurídicas de direito público respondem pelos danos que os seus funcionários, nessa qualidade, causem a terceiros; parágrafo único - Caberá ação regressiva contra o funcionário responsável, nos casos de culpa ou dolo". 
Malgrado a reprodução da responsabilidade objetiva, a exemplo das constituições anteriores, avança a Carta em diversos pontos ao equiparar, para tal fím, a pessoa jurídica de direito público àquelas de direito privado que prestem serviços públicos (concessionárias, permissionárias e autorizatárias), de tal sorte que os agentes ali mencionados (presidentes, diretores, empregados em geral e não apenas o restrito termo funcionários públicos), são postos em paralelo aos agentes públicos no que tange à responsabilidade pelos danos causados a terceiros.

A doutrina compartilha, salvo pequenas variaçōes, do mesmo entendimento, quanto à tormentosa questão do alcance pretendido pelo dispositivo em testilha, abrangendo, à obviedade, os órgãos da Administração Direta, alcançando, da mesma forma, as entidades da Administração Indireta. Esta, por sua vez, compreende apenas as autarquias, as fundações públicas ou de direito privado, instituídas ou mantidas pelo Poder Público, as sociedades de economia mista e as empresas públicas, que estão indubitavelmente sujeitas à aplicação direta do dispositivo constitucional. ${ }^{13}$

Há que se conferir, contudo, significado mais restrito às concessionárias e permissionárias de serviço público, nem sempre pertencentes à Administração Indireta. Em relação a estas, cabivel a responsabilidade objetiva por danos causados no desempenho da atividade concedida ou permitida, devendo a Fazenda responder subsidiariamente (na hipótese de insolvência da concessionária ou permissionária). Ademais, a responsabilização também será cabível se houver má escolha do pretador ou concessionário ou ainda na hipótese de falha na fiscalização de suas atividades.

13 Quanto às concessionárias ou permissionárias, lícito e esclarecedor o entendimento esposado por Almiro do Couto e Silva, para quem o dispositivo constitucional seria aplicável, tão-somente, por via de analogia, a saber. "Não seria nem razoável que a Constituição sujeitasse as pessoas privadas, concessionárias ou permissionárias de serviços públicos ou que explorassem obras públicas, aos princípios que enumera o art. 37, ao lado do da responsabilidade objetiva, tais como o da legalidade, da impessoalidade, da moralidade, da publicidade. do concurso público para o acesso aos cargos, empregos e funções públicas, da vedação de vinculação de vencimentos ou da licitação para a realização dos contratos de obras e serviços, além de outros igualmente a elas inadequados. Todos esses princípios são apenas compatíveis com as entidades, de direito público ou direito privado, criadas pelo Poder Público" (A responsabilidade extracontratual do Estado no direito brasileiro, p. 26-27).

E continua com habitual precisão, "Mas se o $\$ 6^{\circ}$ do art. 37 da Constituição Federal não tem aplicação direta aos concessionários e permissionários de serviços públicos ou de exploração de obras públicas, sobre eles incide, entretanto, por via de analogia. No que se relaciona com os serviços públicos ou com a exploração de obras públicas, quer os danos sejam causados diretamente pelo Estado, quer por particulares a quem o Estado delegue essas atribuiçōes, trata-se sempre de uma atividade eminentemente pública, não se justificando que. na primeira hipótese, as vítimas tenham facilitado o seu acesso ao ressarcimento pela porta da responsabilidade objetiva, enquanto que, na segunda, só the estaria aberto o caminho mais difícil e tormentoso de ter de alegar e provar a culpa do agente do concessionário ou permissionário".

Arremata, "Não se pode esquecer, nesse contexto, que a tendência geral do Direito Administrativo é no sentido de favorecer o administrado sempre que este sofrer um agravo, um prejuizo, por parte dos agentes do Estado, diretamente, ou de particulares que estejam investidos de atribuições de índole pública. De qualquer forma, nestes casos, a responsabilidade do Estado será sempre subsidiária, só respondendo pelo dano na hipótese de insolvência do concessionário ou permissionário, a quem, caracteristicamente, incumbia exercer o serviço público por sua conta e risco". 
A mesma problemática é levantada por ODETE MEDAUAR ${ }^{14}$ que, com a costumeira clareza, preceitua: "União, Estados, Distrito Federal, Municípios, Administração direta e autarquias são as pessoas jurídicas de direito público abrangidas pela responsabilidade objetiva.

"No tocante às pessoas jurídicas de direito privado prestadoras de serviços públicos, podem estar ou não inseridas na Administração.

"Entre as entidades da Administração indireta, dotadas de personalidade jurídica privada figuram as empresas públicas, sociedades de economia mista e a maioria das fundações públicas.

"Para que se enquadrem no referido $\S 6^{\circ}$, deve-se verificar se prestam serviços públicos, o que nem sempre se revela fácil. As dificuldades surgem sobretudo em virtude da existência de uma concepção ampla e restrita de serviço público e em virtude do contraponto entre serviço público e atividade econômica mista. Alguns indicadores podem auxiliar na tarefa: dispositivos constitucionais e de lei que atribuem a certas atividades a condição de serviço público (por exemplo, Constituição Federal, art. 30, V e Lei 9.074/95, art. $1^{\circ}$ ); o serviço público caracterizado como atividade prestacional de responsabilidade do poder público (Constituição Federal, art. 175), tais como: fornecimento de água, coleta de lixo, limpeza e iluminação de ruas, correios, telefone, manutenção de áreas verdes, jardins e praças. Se as entidades acima prestarem serviços públicos, o regime de sua responsabilidade civil por danos a terceiros é o do $\S 6$ ".

Prossegue a insigne jurista paulista. "No tocante às pessoas jurídicas de direito privado não inseridas na Administração, deve-se distinguir, de um lado as concessionárias, permissionárias de serviço público e detentoras de autorização de serviço e de outro as que mantêm, com a Administração, contrato de prestação de serviço ou de obra pública. No primeiro caso, sem dúvida, incide sobre tais entidades a responsabilização objetiva nas atividades vinculadas ao serviço público prestado, ficando sob a égide do direito privado os danos advindos de outras atividades; vem se admitindo a responsabilidade solidária da Administração por má escolha do particular prestador de serviço, por ausência e falha na fiscalização, desde que comprove o nexo causal entre essa conduta e o dano".

E finaliza: "Quanto às obras públicas realizadas por empreiteiras privadas contratadas, as tendências atuais sobre responsabilização assim se apresentam: a) pelo fato da obra, isto é, pela existência da obra, responde somente a Administração: por exemplo: obra púbica que impede acesso a garagem: b) por dolo, negligência, imprudência, imperícia da empreiteira na construção, a responsabilidade é solidária, da Administração e da empreiteira, podendo a vítima escolher quem vai acionar ou acionar ambas". ${ }^{15}$ 
A expressão agente denota sentido amplo, não apenas aludindo aos funcionários (como em todas as Cartas anteriores), mas a todos aqueles que estiverem a serviço da Administração, nessa qualidade, incluindo-se em tal conceito, os colaboradores eventuais, e mesmo os chamados Agentes de Estado ou Membros de Poder. Irrelevante, para a vítima, o título pelo qual o agente faltoso esteja vinculado à Administração, se em caráter permanente ou transitório (em todos os graus de transitoriedade, incluindo colaboradores, excluindo-se, por óbvio, aqueles vínculos remotos).

A locução "nessa qualidade" expressa o liame necessário ao estabelecimento da relação existente entre o evento danoso e o desempenho de atividade junto à Administração. A ação ou omissão perpetrada pelo agente deverá, pois, guardar estreito nexo com a atividade prestada, ainda que ocorra ilegalidade ou abuso em sua conduta comissiva ou omissiva. "Nessa qualidade", portanto, significa, durante o exercício ou em razão do exercício específico da função.

A adoção da expressão "direito de regresso" e não "ação regressiva", outrossim, traz à lume a exigibilidade ou não da via judicial ou da suficiência da via administrativa (garantida a ampla defesa) para que o Estado busque o ressarcimento em regresso em face do agente culposo.

Desde a Carta de 1946, não se cogita da existência de culpa ou dolo do agente para caracterizar o direito à composição do prejuízo causado pela atividade estatal, em razão da adoção da doutrina do risco. A distinção dolo e culpa terá pertinência, tão-somente, na via regressiva, sendo desnecessária sua invocação por parte do Administrado. Além disso, o dolo só agrava a responsabilidade pública por presumir a má escolha.

Inconteste o entendimento da concomitância de teorias supra citadas, restando a teoria objetiva, baseada no nexo causal, a disciplinar a relação Estado-Administrado (sendo irrelevante, portanto, o grau de vinculação do agente com a Administração, bem como a ocorrência de dolo ou culpa), ao mesmo tempo em que a teoria subjetiva, calcada no dolo ou culpa, disciplina a relação interna existente entre Estado-funcionário (ou agente, ou colaborador etc., hipótese em que o grau de vinculação com a Administração bem como a natureza da ação ou omissão deverão ser consideradas).

A obrigação de ressarcir é da pessoa jurídica a que pertencer o agente, devendo a ação ser promovida em face dessa e não do agente causador do dano, valendo o princípio da impessoalidade. Ademais, cumpre lembrar, que a Administração deverá ressarcir nas hipóteses de falha anônima do serviço, bem como por danos ocasionados por ato lícito.

Destarte, outras questões poderiam ser levantadas, como a possibilidade do agente ser demandado pessoalmente (em razão de sua solvência, talvez para fugir dos precatórios); a possibilidade ou conveniência da formação de litisconsórcio entre a Fazenda e o agente faltoso; e a tormentosa questão da denunciação da lide, feita pela Fazenda, do agente faltoso e suas diversas implicações.

Como se vê, construiu-se no país dos mais modernos e abrangentes sistemas de responsabilização pública, malgrado isolada jurisprudência que ainda hesita em aplicá-lo, invariavelmente apegada à interpretação fazendária. Cabe, contudo, torná-lo eficaz, notadamente se levarmos em conta a excessiva demora encontrada no 
pagamento dos precatórios, quando não mesmo o seu puro, simples e proposital não pagamento. Impune, diga-se.

\section{2 - Responsabilidade puiblica por atividade judiciária no direito brasileiro}

\section{1 - Espécies de responsabilidades do juiz}

Não obstante o objeto deste trabalho versar sobre a responsabilidade pública por atividade judiciária inadequada, será necessária a abordagem, ainda que breve, da responsabilidade pessoal do Juiz, sob os prismas político, social e judicial (civil, criminal e disciplinar), conforme a disciplina adotada pelo direito positivo brasileiro.

Mauro Capelleti ${ }^{16}$, em sua consagrada obra, assevera quatro tipos de responsabilidade:

Pela primeira, diferencia-se a responsabilidade do juiz enquanto indivíduo da magistratura como instituição. Distingue, ademais dois subgrupos: responsabilidade em face dos poderes políticos e responsabilidade constitucional.

A segunda modalidade é a responsabilidade social, assumida perante o público em geral, podendo referir-se tanto ao juiz como indivíduo quanto ao Judiciário.

A terceira forma é a responsabilidade jurídica do Estado, que pode ser exclusiva ou concorrente com a responsabilidade pessoal do juiz. Esta última, a quarta modalidade, pode ser penal, civil ou disciplinar.

Há que se ressaltar, contudo, que um único ato do juiz pode gerar todas as espécies de responsabilidade acina descritas.

\subsection{1 - Responsabilidade Política}

A responsabilidade política distingue-se das demais porque seu julgamento ocorre normalmente perante um órgão político, e a sua pena é política, esgotando-se com o afastamento do juiz do exercício da função, além de eventuais penas acessórias. Em sentido amplo, contudo, pode ser considerada como espécie do gênero responsabilidade jurídica, porque prevista e disciplinada em lei.

$\mathrm{O}$ entendimento a respeito da responsabilidade política do juiz no sistema brasileiro é, por evidente, muito deverso daquele existente nos países em que os juízes cumprem funções expressamente políticas, no sentido de serem eleitos ou indicados e destituídos. A responsabilidade política, assim entendida, corresponde aos sistemas em que o juiz não recrutado mediante concurso.

Nos países integrantes da Common law, os processos de impeachment e recall constituem instrumentos de controle político dos juízes. $\mathrm{Na}$ Inglaterra, o juiz poderá ser acusado perante a Câmara dos Lordes, a pedido da Câmara dos Comuns. Nos Estados Unidos, o instituto é alçado à categoria de responsabilidade constitucional

16 Juizes irresponsáveis?. 2 $2^{\text {a }}$ ante. 
(mais do que política, portanto), prevendo alguns estados além do impeachment, o recall de juízes e, inclusive, de decisões judiciais, como bem ilustra Paulo Bonavi$\operatorname{des}^{17}$.

A participação ativa e determinante, ou melhor, vinculante, do juiz no processo criativo do direito, por certo, ensejaria maior controle político (no sentido estrito do termo) sobre sua atividade. Nesse sentido a lição Ada Pellegrini Grinover ${ }^{18}$, “...o problema da responsabilidade do juiz é particularmente sentido nos países que the atribuem a tarefa de participar do ato de criação ou de execução da lei, surgindo, então, com a pergunta espontânea quis custodiet custodes?, a questão de sua responsabilidade política".

E acrescenta em conclusão, mais adiante "Assim, não se põe, no Brasil, o problema da jurisprudência criativa e do direito livre, sendo o seu papel, reconhecidamente, o de interpretação ou de integração da norma".

Cabe salientar, a esta altura, dois pontos fundamentais nesta discussão. O primeiro diz respeito ao controle da atividade jurisdicional desempenhada pelo juiz enquanto agente a sua principal função, qual seja, a de decidir. A segunda, diz respeito à atuação do Poder Judiciário em face dos demais Poderes.

Pela primeira, entende-se que não existe no Brasil controle político do ato jurisdicional típico e mesmo das demais atividades do juiz enquanto agente do Estado e mesmo, em sua vida privada enquanto pessoa.

A livre apreciação dos fatos e das provas, elementos informadores da liberdade de convicção, pedra angular de um sistema caracterizado pela independência e liberdade do magistrado, são assegurados pela Constituição que, contudo, o condiciona à motivação e fundamentação das decisões judiciais (art. 93, IX).

Descabe, portanto, qualquer forma de controle político do mérito da decisão judicial. Desta forma, temos assegurada a transparência dos motivos ideológicos que estribaram a decisão, bem como o escolpo de assegurar o conhecimento de tais razões às partes (para fins de interposição de eventual recurso) e mesmo à sociedade (como forma de responsabilização e satisfação social).

No plano da vida pessoal ou de sua conduta enquanto profissional, o Juiz responderá no âmbito disciplinar, penal e civil. Ademais, ainda que aventada a hipótese do descumprimento da Constituição por parte do juiz, estaria ele respondendo juridicamente e não politicamente.

Pela segunda, apontam-se os limites da atuação do Poder Judiciário, em relação às atividades precípuas desempenhadas pelos outros Poderes, o Executivo e o Legislativo.

Os atos administrativos sujeitam-se ao princípio da legalidade, sendo o controle da legalidade de tais atos desempenhado, no Brasil, pelo Poder Judiciário por meio do sistema de jurisdição una. Controle este, a propósito, que exclui o do mérito do

17 Ciência política, p. 353-354.

is A responsabilidade do juiz brasileiro, p. 19-21. 
ato administrativo, plasmado nos princípios da conveniência e oportunidade, de exclusiva alçada da Administração, exceção feita às ações popular e civil pública.

Quanto ao controle dos atos legislativos, somente ficarão ao alcance do jurisdicional nas diversas mas taxativas hipóteses de controle judicial e repressivo de constitucionalidade.

A responsabilidade política do juiz, enquanto agente público no Brasil encontra, assim, regulamentação deficiente e bastante restrita, tendo em vista existência de importante lacuna, hábil para ensejar a inexistência da responsabilidade política dos magistrados excetuada a dos integrantes do Excelso Pretório, pois estes não ingressam na carreira mediante concurso público de provas e títulos mas por critérios de indicação e nomeação políticos. Vejamos, portanto.

A Constituição de 1988 prevê o sistema de responsabilização para o julgamento dos "crimes de responsabilidade". Por intermédio deste sistema, caberá ao Senado Federal (art. 52, II) processar e julgar os Ministros do Supremo Tribunal Federal; ao STF os Ministros dos Tribunais Superiores (art. 102, I, b); ao Superior Tribunal de Justiça os dos desembargadores dos Tribunais de Justiça dos Estados e Tribunais Regionais Federais; aos Tribunais de Justiça dos Estados, os dos demais juízes estaduais dos Tribunais de Alçada e juízes de direito (art. 96, III).

A Lei 1.079, de 10.04.1950, que define os crimes de responsabilidade (ou políticos), dispõe, em seu art. 39.

"São crimes de responsabilidade dos Ministros do Supremo Tribunal Federal: 1) alterar por qualquer forma, exceto por via de recurso, a decisão ou voto já proferido em sessão do Tribunal; 2) proferir julgamento quando, por lei, seja suspeito na causa; 3) exercer atividade político-partidária; 4) ser patentemente desidioso no cumprimento dos deveres do cargo; 5) proceder de modo incompatível com a honra, dignidade e decoro de suas funções".

Os artigos seguintes disciplinam seu processamento ${ }^{19}$

Cabe a menção à lição de Ruy Rosado dé Aguiar Júnior ${ }^{20}$, ao apontar as grosseiras falhas de nosso sistema.

"É preciso reconhecer, portanto, de um lado, a inoperância da lei para o caso da responsabilidade política dos ministros do supremo Tribunal Federal, jamais aplicada, e, de outro, a existência de um vazio legislativo em relação aos demais juízes. O primeiro dado não impressiona, pois bem pode

19 A Carta de 1988, em eu art. 95, I, garante a vitaliciedade, condicionando a perda do cargo a "sentença judicial transitada em julgado". Desta forma, apenas por sentença proferida pelo Poder Judiciário, e não por julgamento político, o juíz perderá o cargo. A responabilidade política dos demais magistrados não encontra regulmentação legal, não estando disciplinada em qualquer lei ordinária. Apenas os Ministros do Supremo Tribunal Federal, portanto, serão submetidos a esta espécie de responsabilização que, diga-se, jamais foi aplicada.

20 A responsabilidade política e social dos juizes nas democracias modernas, p.37. 
acontecer que baste a existência de tal procedimento, sem que jamais tenha a necessidade de ser aplicado; o segundo defeito, todavia, é grave, vez que o ordenamento jurídico do país deveria contar com a estruturação legal de um instituto que, apesar de escassa incidência, pode ser decisivo em certas circunstâncias, como mostra a nossa recente história política".

A criação do Conselho Nacional da Magistratura (ou recriação, após sua previsão pela Lei Orgânica e extinção pela Carta de 1988), poderia servir de supedâneo hábil para suprir tal lacuna.

\subsection{2 - Responsabilidade Social}

Entende-se, por esta forma de responsabilidade, a prestação de contas à sociedade (por meio de organismos representativos do que se chama indeterminadamente de "sociedade civil organizada") e imposição de respectivas sanções. A incompatibilidade desta forma de responsabilização soa evidente, acaso se considere o contexto da magistratura profissional e sua tecnicidade.

A motivação e fundamentação da decisão judicial, bem como a publicidade dos atos judiciais, como já visto, servem, de certa maneira, à satisfação prestada à sociedade pelo exercício da função jurisdicional. A eficiência da ação fiscalizadora da sociedade, portanto, dependerá da adequada utilização desses meios pelos dos quais se efetiva o conhecimento público dos atos e das razões justificadoras da escolha.

Malgrado nosso sistema, baseado no recrutamento mediante concurso público e marcado pela garantia da vitaliciedade, não faça a previsão de efetivos instrumentos de reprovação social como o recall ou a não recondução ao cargo, tem-se assistido a um interesse cada vez maior da sociedade (perceptível pelo espaço cada vez maior ocupado na mídia) pela atividade judicial.

A responsabilidade social, no sistema pátrio, é de ordem meramente ética, recaindo sobre a aprovação da ação judicial por parte de parcelas mais ou menos significativas da população. ${ }^{21}$ Neste diapasão, convém ressaltar que é próprio da atividade jurisdicional a existência, quase inevitável, de uma parte vencedora e outra perdedora a cada demanda.

21 Pertinente a lição de Ruy Rosado de Aguiar Júnior, cujos ensinamentos merecem ser transcritos. "O juiz responde perante a sociedade pelo exercício de sua função, que é, como as demais funções do Estado, meio de realização dos valores fundamentais por ela consagrados. No estado democrático, o juiz assume o compromisso de exercer o poder estatal de acordo com os princípios orientadores do ordenamento jurídico que o investiu no cargo e de onde the advém a força da decisão" (ibidem).

E mais adiante, "A responsabilidade social se põe diretamente entre o juiz e a sociedade como um todo, e permite um juizo ético de reprovaçāo, fundamentado na expectativa de que ele exercerá do melhor modo possível as funções do seu cargo, tendo em vista a base democrática que anima essa sociedade. Há para o juiz o dever de atender a tal expectativa, embora a esse dever de prestação não corresponde nenhuma responsabilidade jurídica, pois o descumprimento não ensejará aplicação de sanções jurídicas". 
À guisa de fechamento, e a vingar tal instrumento de controle, estaria o juiz fadado a julgar de acordo com a "voz da turba", temeroso por desagradar os anseios da população em "fazer justiça" (o linchamento, o saque e a depredação, lembremos, pertencem a tal espécie) cedendo espaço o julgamento técnico e sereno à decisão emotiva e acalorada, por covardia, crê-se. Ter-se-ia, por fim, o juiz populista.

É possível que em uma sociedade de doutos de espírito e intelecto, ou sem disparidades gritantes e com apreciável grau de homogeneidade, seja possível desenvolver algum tipo de responsabilização social.

Os mecanismos constitucionais existentes (publicidade, motivação, fundamentação, duplo grau de jurisdição entre outros), o sistema de responsabilização multifacetado construído ao longo dos tempos, o equilibrio entre as funções do Estado, a atuação das Corregedorias, do Ministério Público, o chamado quinto constitucional e, enfim, a criação do Conselho Nacional da Magistratura, constituem (e em relação a este último constituiria) instrumentos que. se utilizados, assegurariam tal controle de forma racional e serena.

O papel da imprensa (por alguns denominada de "Quarto Poder"), por meio do destaque e interesse dados pelos meios de comunicação, ademais, tem sido dos principais instrumentos de acompanhamento do desempenho profissional e social do Judiciário.

A realização ou confirmação das expectativas é, portanto, o norte que deve guiar a atividade jurisdicional, independentemente do conteúdo ideológico de sua decisão pois, como já visto, é da natureza desta atividade o descontentamento de uma das partes.

O exercício desta forma de controle, se exercido de forma responsável e não leviana ou precipitada, tende a somar esforços ao aperfeiçoamento das atividades judiciárias. Na verdade, o juiz deve convencer a sociedade do acerto de sua decisão, pois nem sempre aquela estará em consonância com a esperada pela maioria ou pela imprensa, mas sim, de acordo com as provas trazidas à sua apreciação, analisadas sob o prisma da lei, votada e aprovada pelos representantes mais diretos do povo.

\subsection{3 - Responsabilidade Juridica}

De início, cumpre ressaltar que a responsabilidade jurídica, em sentido amplo, abrange a política, eis que esta é exercida, como visto, na forma da lei.

Ademais, será tratada a partir do próximo tópico, pois que este é o escopo primordial do presente estudo (e mais especificamente a responsabilidade do Estado e não do juiz), constando neste momento do trabalho apenas para delimitar seu espaço metodológico.

Apontam-se, como espécies de responsabilidade jurídica do juiz, aquelas de natureza civil, criminal e disciplinar ou administrativa.

Destacam-se, portanto, a título meramente exemplificativo quanto à menção dos dispositivos legais, a responsabilidade civil, insculpida nos arts. 133 do Código de Processo Civil (como forma de prevenção ou reparação); a responsabilidade penal, prevista nos Código Penal e de Processo Penal (crimes típicos de agente público ou comuns com reflexos em razão da condenação), bem como, por abuso de autoridade, 
na Lei n. 4.898, de 1965; a responsabilidade administrativa ou disciplinar, regulamentada pela Lei Orgânica da Magistratura Nacional, em seu art. 49 (com o escopo de sanear a instituição, punindo o juiz faltoso).

A regra, contudo, tem sido a da irresponsabilidade pessoal do juiz, nos termos do art. $37, \S 6^{\circ}$ da Constituição.

\section{2 - Evolução Histórica do Instituto no Direito Positivo Brasileiro}

O propósito deste tópico consiste em elencar, observada a sequiência cronológica, os textos disciplinadores do instituto da responsabilidade (pessoal ou estatal) por atividade judiciária, vislumbrando seu desenvolvimento histórico. A evolução histórica do instituto ora estudado, no direito português, será enfocada a partir de seu interesse para o direito brasileiro, descabendo o estudo do período anterior ao Brasil-Colônia.

Ademais, a crítica aprofundada bem como eventuais comentários ocorrerão em sede própia, qual seja, na análise dos dispositivos constantes de nosso direito positivo.

Durante o período colonial. a matéria teve sua regulamentação dada pelas Ordenaçōes do Reino de Portugal. Os dispositivos que tratam do assunto podem ser encontrados nas Ordenações Afonsinas, publicada por Afonso V em 1446 (Livro III, Título CXXVII e Livro V, Título XXXI); Manuelinas, de 1503 (Livro V, título LVI); e Filipinas, por Filipe II de 1603. Quanto às últimas, vigoraram em Portugal até 1867 e, no Brasil, até a vigência do Código Civil de 1916. Consolidando textos promulgados, e buscando inspiração nos Direitos Romano, Canônico, nas Siete Partidas e no Fuero Real tais construções representaram importante avanço na positivação do direito, ainda nos primórdios da era das codificações.

Ruy Rosado de Aguiar Júnior ${ }^{22}$, traz à colação, os dispositivos das Ordenações Filipinas, predominando, no período, a responsabilidade pessoal do juiz.

"As Ordenações Filipinas adotaram o princípio da responsabilidade pessoal do Juiz, do que se recolhem diversas passagens: Livro I, Título LXXXVIII, $\$ 16$ - '...e o juiz que isto não cumprir, pagará ao órfão toda a perda e dor, que por isso se lhe causar'; Livro III, Título LXII, $\S 5^{\circ}-$ '...e o julgador, que os tais atos processou, será obrigado às custas no caso, que processou sem citação, ou com citação nula'; Livro IV, Título CII, $\S 7^{\circ}-$ 'E faça o dito Juiz de tal maneira, que por sua culpa ou negligência os bens dos órfãos não recebam dano, porque todo o dano e perda que receberem pagará por seus bens'."

E prossegue, demonstrando a preocupação do legislador com a responsabilidade exclusivamente pessoal, exigindo a permanência do magistrado, por determinado período, na jurisdicão que servira.

22 Op. cit., p. 14. 
"A fim de garantir essa responsabilidade pessoal, a exemplo do que ocorria na Espanha, era o juiz obrigado a dar residência, com o dever de permanecer por certo tempo no lugar onde exercera a função, para responder as reclamações dos eventuais lesados. Para isso, o novo Juiz do lugar, nos dez dias seguintes a sua posse, deveria proceder à devassa sobre o juiz anterior, a chamada 'janeirinha', regulada nas Ordenações Filipinas, Livro 1, Título LXV, §§ 39 a 72, enviando seu resultado ao Corregedor da Coroa".

A responsabilidade pessoal do Juiz continuou a ser a nota predominante após a independência, nada dispondo a Carta de 1824 a esse respeito. A propósito, mesmo com a independência, o Brasil continuou sendo regido por leis portuguesas, até que fossem editadas normas brasileiras.

A primeira lei a disciplinar a responsabilidade do juiz foi o Codigo de Processo Criminal de 29.11.1832, abarcando as hipóteses de prevaricação (art. 129) e peita (arts. 130 e 131), com reflexos na esfera civil (se a decisão for justa, pena de perda do emprego, inabilitação por um ano para qualquer outro, multa de três vezes o valor da peita e prisão de três a nove meses; se injusta, prisão de seis meses a dois anos) e criminal (caso em que soferá a mesma pena a que condenou a vítima, menos à morte, se a execução não tiver ocorrido, caso em que será condenado à prisão perpétua).

A matéria, ademais, recebeu disciplina dada pelo Decreto n. 737, de 25.11.1850, objetivando a regulamentação do processamento das causas comerciais (as cíveis continuavam disciplinadas pelas Ordenações Filipinas até 19.9.1890 quando o Decreto n. 763 mandou aplicá-lo também ao processamento das causas cíveis), cujo teor do art. 677 é o que segue, "As nulidades arguidas não sendo supridas, ou pronunciadas pelo Juiz, importarão: $\S 1^{\circ}-\mathrm{A}$ anulação do processo na parte respectiva, se elas causaram prejuízo àquele que se argüiu; $\S 2^{\circ}-$ a responsabilidade do Juiz".

Inova o legislador quando da edição do Código Penal de 1890 (Dec. 847. de 11.10.1880), ao impor ao Estado, a teor de seu art. $86^{23}$, o dever de indenizar o réu condenado por sentença criminal e posteriormente reabilitado. Enumera, ademais, uma série de crimes afetos ao abuso de autoridade, respondendo, nestes casos. pessoalmente o juiz por prevaricação, demora ou denegação de justiça, julgar sob suspeição ou impedimento, conduta desregrada, desídia, entre outros.

A Constituição Republicana de 1891 nada diz a respeito da responsabilidade por atividade judiciária, seja pessoal do juiz ou objetiva do Estado, disciplinando o instituto da responsabilidade pública no geral.

23 Art. 86: "A rehabilitaçāo consiste na integraçāo do condenado em todos os direitos que houver perdido pela condemnação, quando fôr declarado innocente pelo Supremo Tribunal Federal. em consequencia de revisão extraordinária da sentença condemnatória.

$\$ 1^{\circ}$ - a rehabilitação resulta immediatamente da sentença de revisão passada em julgado.

$\$ 2^{\circ}$ - a sentença de rehabilitação reconhecerá o direito do rehabilitado a uma justa indemnização, que será liquidada em execição pôr todos os prejuizos sofridos com a condemnação.

A Nação. ou o Estado, são responsáveis pela indemnização". 
É com a edição do Código Civil de 1916 que a questão toma corpo, ensejando profícuo debate doutrinário. $\mathrm{O}$ art. 15 constitui o marco, verdadeiro divisor de águas na evolução da responsabilidade pública, ao dispor: "As pessoas jurídicas de direito público são civilmente responsáveis por atos dos seus representantes que nessa qualidade causem danos a terceiros, procedendo de modo contrário ao direito ou faltando a dever prescrito por lei, salvo o direito regressivo conta os causadores do dano" 24

As Constituições de 1934 e de 1937 mantém o silêncio sobre a disciplina específica do instituto, valendo assim a regulamentação genérica da responsabilidade pública do Código Civil. ${ }^{25}$

Com a promulgação da primeira Constituição Republicana, os Estados passaram a ter competência para promulgar seus próprios Códigos de Processo Civil, que afinal restaram assemelhados tendo em vista a utilização do Decreto n. 737 como paradigma (alguns estados sequer promulgaram seus diplomas processuais, permanecendo em vigor o aludido decreto). A Constituição de 1934 restabeleceu a competência da União para legislar em matéria processual, posição mantida pela Constituição de 1937. A promulgação do Código de Processo Civil de 18.09 .1939 , encerra a era dos códigos estaduais, revogando-os, bem como o Decreto $737^{26}$.

Em 1940, o Código Penal, além dos crimes prticados por funcionários públi$\cos ^{27}$, tipificou no art. 350 , o crime de exercício arbitrário ou abuso de poder ${ }^{28}$.

24 A par do dispositivo citado, de importância crucial, outros aludem especificamente à responsabilidade do Juiz por danos causados às partes. O art. 294 ("Ficará subsidiariamente responsável o Juiz que conceder a alienação fora dos casos e sem as formalidades do artigo antecedente, ou não providenciar a sub-rogação do preço e conformidade com o parágrafo único do mesmo artigo"); o art. 420 ("O Juiz responde subsidiariamente pelos prejuízos que sofra o menor em caso de insolvência do tutor, de the não ter exigido a garantia legal, ou de o nāo haver removido, tnto que se tornou suspeito"); o art. 421 ("A responsabilidade será pessoal e direta, quando o Juiz não tiver nomeado tutor, ou quando a nomeação não houver sido oportuna"); por fím os arts. 1.551 ("Consideram-se ofensivos da liberdade pessoal I - o cárcere privado: II - a prisão por queixa ou denúncia falsa e de má fé, III - a prisão ilegal") e 1552 ("No caso do artigo antecedente, n. III, só a autoridade, que ordenou a prisão, é obrigada a ressarcir o dano").

25 Em relação à Carta de 1934, Pontes de Miranda invoca a estreita exegese do dispositivo constitucional, "A Fazenda federal e a Fazenda estadual não são responsáveis pelos prejuizos decorrentes das decisões judiciárias, inclusive dos tribunais militares, do Tribunal de Contas, da Justiça eleitoral e da Justiça do Trabalho" (Comentários à Constituição, vol. II, p. 487).

$26 \mathrm{O}$ art. 121 do Código de Processo Civil de 1939. assim dispõe:

"O juiz será civilmente responsável quando:

I - no exercício das suas funções, incorrer em dólo ou fraude;

II - sem justo motivo, recusar, omitir, ou retardar providências que deva ordenar ex officio, ou a requerimento da parte.

As hypotheses no n. II sómente se considerão verificadas decorridos dez (10) dias da notificação ao juiz, feita por pela parte por intermédio do escrivão da causa".

27 Peculato - arts. 312 e 313, concussão - art. 316; corrupção - art. 317; prevaricação - art. 319 , advocacia administrativa - art. 321.

28 "Ordenar ou executar medida privativa de liberdade individual, sem as formalidades legais ou com abuso de poder". 
A propósito, a Lei n. 4.898, de 9.12.1965, ao dispor sobre o abuso de autoridade. em seus arts. $4^{\circ}$, a ("ordenar ou executar medida privativa de liberdade individual, sem as formalidades legais ou com abuso de poder") e $d$ ("deixar o juiz de ordenar o relaxamento de prisão ou detenção ilegal que lhe seja comunicada"), prevê o ressarcimento do dano em seu art. $6^{\circ}$ ("O abuso de autoridade sujeitará o seu autor à sanção administrativa, civil e penal). $\S 2^{\circ}$ ("A sanção civil, caso não seja possível fixar o valor do dano, consistirá no pagamento de uma indenização de quinhentos a dez mil cruzeiros").

O diploma adjetivo. Código de Processo Penal de 1942. aborda a espinhosa questão do erro judiciário em seu art. 630, inovando, contudo, ao atribuir tal responsabilidade diretamente ao Estado, condicionando a indenização à procedência da revisão criminal (e não à reabilitação). excluindo de maneira absolutamente injustificada, a hipótese da ação privada ${ }^{29}$

A Constituição Federal de 1946, nada diz em relação à responsabilidade pessoal do Juiz ou do Estado por atividade judiciária inadequada, dispondo, tão-só, sobre o instituto da responsabilidade pública em sua generalidade, o mesmo ocorrendo com as Cartas de 1967 e a Emenda n. 1, de 1969.

O Código Processual Civil de 1973, em seu art. 133, reproduz idêntica regra à contida no diploma formal de 1939 (art. 121), ao dispor sobre a responsabilidade pessoal do Juiz, por ação ou omissão, ao obrar com dolo ou fraude, bem como denegar justiça. condicionando, contudo. a eficácia do dispositivo a uma inverossímel interpelação do Juiz por "seu" Escrivão 30 .

A Lei Complementar n. 35, de 14.3.1979 (Lei Orgânica da Magistratura Nacional), reproduz o dispositivo supracitado em seu art. 49 , ampliando sua incidência às jurisdições criminal, eleitoral, trabalhista e militar. Regula, ademais, a aposentadoria do Juiz por negligência manifesta a incapacitação para o serviço em seu art. $56^{3 !}$, a partir de determinação de um inexistente Conselho Nacional da Magistratura.

29) O art. 630 será objeto de análise mais acurada no próximo capítulo do presente trabalho ("O Tribunal, se o interessado o requerer, poderá reconhecer o direito a uma justa indenização pelos prejuízos sofridos. $\$ 1^{\circ}$ - por essal indenizatção, que será liquidado no juízo civel. responderá a União, se a condenação tiver sido proferida pela Justiça do Distrito Federal ou de Território, ou o Estado se o tiver sido pela respectiva justiça. $\$ 2^{\circ}-\mathrm{A}$ indenização não será devida: a) se o erro ou a injustiça da condenação proceder de ato ou falta imputável ao próprio impetrante, como a confissão ou a ocultaçāo de prova em seu poder: b) se a acusação houver sido meramente privada"). 30 Como se depreende do scu teor: "Responderá por perdas e danos o Juiz, quando: I - no exercício de suas funções, proceder com dolo ou fraude; II - recusar, omitir ou retardar, sem justo motivo, providência que deva ordenar de ofício, ou a requerimento da parte. Parágrafo único Reputar-se-ão verificadas as hipóteses previstas no n. II só depois que a parte, por intermédio do Escrivão, requerer ao Juiz que determine a providência e este não the atender o pedido dentro de dez (10) dias".

31 O teor do dispositivo é o que segue: "O Conselho Nacional da Magistratura poderá determinar a aposentadoria, com vencimentos proporcionais ao tempo de serviço, do magistrado: 1 - manifestamente negligente no cumprimento dos deveres do cargo: II - procedimento incompatível com a dignidade, a honra e o decoro de suas funçōes; III - de escassa ou insuficiente capacidade de trabalho, ou cujo proceder funcional seja incompativel com o bom desempenho das atividades do Poder Judiciário". 
A Carta de 1988, além de assegurar ampla responsabilização por ação ou omissão causada por agente (em texto inequívoco expresso em seu art. $37, \S 6^{\circ}$ ), dispõe ainda (em seu art. $5^{\circ}, \mathrm{LXXV}$ ) sobre o ressarcimento do erro judiciário, alçando-o à categoria de direito fundamental individual, ao lado da prisão por tempo excessivo, com o seguinte teor, "O Estado indenizará o condenado por erro judiciário, assim como o que ficar preso além do tempo fixado na sentença".

No que pese a amplitude apresentada pelo quadro atual de nosso direito positivo, a jurisprudência dominante em sido no sentido da admissão da responsabilização do Estado, com conseqüente dever de ressarcimento, restritas à hipóteses de previsão expressa e específica em lei. a teor do erro judiciário criminal constatado após processo de revisão.

Cabível, destarte, a opinião esposada por João Sento $S^{3}{ }^{32}$ para quem

"As considerações feitas ao longo deste trabalho autorizam a conclusão de que não se justifica a exigência de um texto que estabeleça expressamente a responsabilidade da Fazenda Pública por atos dos juízes".

Prossegue, citando Rivero,

"No que concerne especificamente aos atos judiciais, também não faz sentido hoje o "principle archaique de l'irresponsabilité de la puissance publique sans texte", no dizer de Rivero. Na França, a obrigação de reparar tem sido imposta ao Estado pela jurisprudência em casos não declarados em lei. Na Itália, a Corte Constitucional entendeu que "o silêncio quanto à responsabilidade do Estado não a exclui".

Nos demais casos, persiste a tese da responsabilidade pessoal do juiz e da irresponsabilidade estatal, fundadas nos argumentos da soberania do Poder Judiciário, na independência da Magistratura, na qualificação especial conferida ao Juiz, e, principalmente, na autoridade da coisa julgada.

Adotados tais argumentos, inaplicar-se-á a regulamentação objetiva constante não do texto constitucional atual (que ao empregar o vocábulo "agente" dirime a controvérsia), mas das disposições constitucionais anteriores.

As antinomias existentes entre alguns desses dispositivos, os problemas decorrentes da má técnica legislativa e a eventual inconstitucionalidade da lei ordinária em face de preceitos claros e inequívocos insculpidos na Lei Maior, serão analisados a seguir.

\section{3 - Do Sistema no Direito Positivo Contemporâneo}

Após a breve análise de sua evolução histórica, passa-se ao exame mais aprofundado dos problemas decorrentes do complexo sistema positivo contemporâneo. 


\subsection{1 - Da Tutela Constitucional e seus Efeitos}

No que concerne à aplicação do art. $37, \S 6^{\circ}$ da Constituição Federal, aos danos provenientes da atividade judiciária, empresta-se a argumentação já expendida no curso deste trabalho, sobre a caracterização da aludida atividade como espécie de serviço público em sentido amplo, da garantia de acesso à prestação jurisdicional ao cidadão como direito fundamental, bem como do magistrado como seu agente. Concordes todos, doutrina e jurisprudência, passa-se à análise de seus efeitos no ordenamento positivo vigente.

A interpretação a ser dada ao dispositivo do art. $37, \S 6^{\circ}$ da Constituição há de ser a mais elástica possível. $O$ dispositivo não dá margem a dúvidas ao incluir o magistrado no rol de agentes causadores de danos. A exegese do dispositivo implica na aceitação da responsabilidade direta e objetiva do Estado, cabendo a análise do comportamento doloso, culposo ou mesmo lícito, à sede regressiva.

Ademais, o dispositivo abrange não só o dano oriundo de ação ou omissão ilícita mas, também, advindo de comportamento lícito, de qualquer ente físico ou jurídico, vinculado a qualquer título ao Estado. Inclui-se, destarte, a figura do magistrado, dos auxiliares, da falha da máquina judiciária, do comportamento lícito etc.

As disposições da Constituição Federal, contidas em seu art. $5^{\circ}$, inc. LXXV, torna incondicional o ressarcimento, revoga o dispositivo restritivo da legislação processual penal e acrescenta a hipótese da prisão acima do tempo previsto.

A regra do art. $37, \S 6^{\circ}$ abrange todas as demais hipóteses de maneira clara, bastando a constatação do liame entre a conduta do agente (sob qualquer vínculo com a Administração), lícita ou ilícita, e o dano injustamente sofrido pelo destinatário da atividade judiciária. Conjuga-se, além disso, a relação jurídica objetiva estabelecida entre o Estado e a vítima do dano injusto, com a subjetiva existente entre o Estado e o agente causador do dano.

Observem-se seus efeitos em relação aos dispositivos infraconstitucionais.

$\mathrm{O}$ art. $37, \S 6^{\circ}$ da Carta de $1988 \mathrm{ab}$-roga, indubitavelmente, o vetusto dispositivo do art. 15 do Código Civil, bem como as previsões específicas constantes do texto substantivo relativas à responsabilidade pessoal do juiz (que já fora revogada pelo Código de 1939 e pela Constituição de 1946).

Quanto aos dispositivos processuais penais, a saber o art. 630 do Código de Processo Penal e da Lei n. 4.898, de 1965.

A previsão constante do art. $5^{\circ}, \mathrm{LXXV}$, ao mesmo tempo, guinda à categoria de garantia constitucional, a tutela conferida à vítima de erro judiciário civil ou penal, bem como inova em muito ao ampliar a responsabilidade à hipótese do condenado ficar preso além do tempo fixado na sentença. Realça, em destaque, especificando duas situações que o comando genérico do art. $37, \S 6^{\circ}$ continha.

Art. $5^{\circ}$, LXXV:

"O Estado indenizará o condenado por erro judiciário, assim como o que ficar preso além do tempo fixado na sentença".

O Dispositivo do art. $5^{\circ}, \mathrm{LXXV}$, que entendemos desnecessário em razão da previsão explícita do art. $37, \S 6^{\circ}$, referenda, ademais, os dispositivos da Lei 4.898 , de 9.12.1965. 
Assim, valida ao mesmo tempo em que derroga o art. 630 do CPP, pois inexige a desconstituição prévia do julgado criminal, bem como a hipótese excludente da ação penal privada. Descaracteriza, por fim, a aparente discricionariedade do ato de ressarcir que a expressão "poderá" ensejava.

É o ensinamento de Yussef Said Cahali ${ }^{33}$. "O texto constitucional, assegurando a reparação à vítima do erro judiciário, não condiciona o exercício da pretensão indenizatória ao prévio acolhimento de revisão da sentença condenatória" ${ }^{34}$

Ademais, extrapola o dispositivo o estrito campo do erro judiciário penal, conforme bem apontado por A.B. Cotrim Neto ${ }^{35}$,

"Com relação ao estabelecido nesse mencionado inciso LXXV da Carta da União que impõe ao Estado indenizar a vítima de erro judiciário, entendemos que seu alcance vai além do que se dispusera no art. 630 do CPP, visto como a referência ao 'condenado por erro judiciário', posta numa cláusula garante de 'direitos e deveres individuais e coletivos' - qual o art. $5^{\circ}$ do Diploma de 1988 - tem aplicação em todos os campos em que o indivíduo possa ser condenado: no juízo criminal, como no civil, no trabalhista ou no militar e até no eleitoral, enfim, onde quer que o Estado, mesmo através do Ministério Público, tenha sido provocador da condenação".

À guisa de conclusão, vai além a dimensão da inovação constitucional ao encerrar a reiterada justificativa regaliana, a embasar a irresponsabilidade pública por serviço judiciário inadequado, fundada na previsão legislativa explícita à permissão ressarcitória.

Neste sentido, pertinente a lição de Luiz Antonio Soares Hentz ${ }^{36}$,

“A novidade, em termos constitucionais, acredita-se, não ter sido ainda entendida, quanto à adequada dimensão do problema do erro judiciário. Antes da Constituição Federal de 1988, reclamava-se autorização legislativa dando amparo à condenação do Estado ao ressarcimento de danos oriundos da função jurisdicional - como que uma licença do ordenamento jurídico para a imputação do dever (relembre-se que o princípio da soberania era dominante). Pois foi justamente para insẹrir a cláusula de garantia no rol

33 Responsabilidade civil do Estado, p.603.

34 Comunga desta posição Luiz Antonio Soares Hentz, nestes termos, "A garantia ao lesado por erro judiciário tem uma dimensão deveras ampla no que concerne à indenização. Quer dizer, antes de tudo, que o enfoque restritivo do art. 630 do CPP cedeu lugar para abarcar todas as hipóteses de erro judiciário e de prisão indevida, acabando com a discussão sobre a lógica da exclusão dos erros oriundos de ação penal privada e, por ser incondicionado o direito ora proclamado, independe da revisão criminal para sua postulação" (Indenização do erro judiciário, p. 62).

35 Da responsabilidade do Estado por ato de juiz em face da Constituição de 1988, p. 45.

36 Op. cit., p. 62. 
dos direitos individuais que o legislador inovou, não querendo isso dizer, absolutamente, que tenha descurado da responsabilidade estatal.

O dever do Estado e o direito do cidadão, com efeito, andam de mãos dadas na Constituição Federal, com a garantia do art. $5^{\circ}$. LXXV, sendo complementada pelo encargo cominado à Administração Pública no art. $37, \S 6^{\circ}, 37$

No tocante aos dispositivos do diploma processual civil e da Lei Orgânica da Magistratura Nacional, reside o cerne da controvérsia.

O Código de Processo civil de 1939, não encontrou, à época de sua edição. comando constitucional que o confrontasse ou sobrepusesse. A questão surge, pois, com a Constituição de 1946, ao dispor sobre a responsabilidade objetiva do Estado, sem subtrair de seu alcance os atos jurisdicionais. Entendeu a melhor doutrina. com a qual há que se comungar. que a aludida omissão incluiu, em razão do irrefutável princípio da unicidade do poder estatal, a responsabilidade por atos jurisdicionais.

A partir do art. 194 do texto da Carta de 1946 (reproduzido em 1967, 1969 e 1988), emerge a problemática de eventual antinomia entre o comando constitucional e a disposição processual ordinária de 1939 (reproduzida em 1973 e pela Loman em 1979).

Aventam a constitucionalidade, sustentando caber tanto ao Estado quanto ao juiz, ficando a escolha ao interessado, boa parte da melhor doutrina ${ }^{38}$. à qual somamos a nossa opinião.

Neste diapasão, cumpre discordar do insigne jurista potiguar Mário Moacyr PORTO $^{39}$, ao atribuir esta posição ao comodismo e simplificação temerosa de enfrentar o tema. Não parece ser este o perfil dos trabalho dos autores cujo entendimento, acredita-se, deve prevalecer. Literalmente, "Autores há que, para fugirem à dificuldade do assunto, opinam que o prejudicado tem a opção de acionar o Estado ou o juiz, em face do disposto nos arts. 133 e 107 da CF, o que nos parece um acomodado ecletismo, francamente insatisfatório".

Esclarecedora a lição da professora da velha e sempre nova academia de Direito do Largo de São Francisco, Ada Pellegrini Grinover ${ }^{40}$, ao comentar a antinomia aparente em face da Constituição anterior,

37 Ultrapassado, portanto, este entendimento até então predominante de se trazer à colação a lembrança do já citado leading case brasileiro (RE 32.518, publicado na RTJ 39/190, relator Min. Villas-Boas), em que foi apreciada ação proposta contra o Estado do Rio Grande do Sul, por alegada desídia do juiz, que permitira a prescrição de queixa-crime oferecida contra jornalista. Lapidar o voto do Min. Aliomar Baleeiro, que restou vencido (juntamente com o Min. Adalício Nogueira) pela responsabilidade do Estado por ato jurisdicional.

38 Ada Pellegrini Grinover (op. cit., p. 10), Luiz Antonio Soares Hentz (op. cit. p. 63-66); Yussef Said Cahali (op. cit. p. 593-645); Augusto do Amaral Dergint (op. cit. p. 225-230), Giovanni Ettore Nanni e Oreste Nestor de Souza Laspro.

39) Responsabilidade do Estado pelos atos de seus juizes. p. 12.

40 A Responsabilidade do juiz brasileiro, p. 10. 
"Contra o Estado, e independentemente da indagação a respeito da culpa ou dolo, poderá o prejudicado pelo ato jurisdicional agir, obtendo a reparação prevista no art. 108 da Constituição. Nos casos dos arts. 133 do Código de Processo civil e 49 da Lei Orgânica, o Estado poderá exercer a ação de regresso contra o juiz. E. nesses mesmos casos, poderá o prejudicado. se o quiser, acionar diretamente o juiz, ao invés de valer-se da ação de responsabilidade civil contra o Estado".

Ruy Rosado de Aguiar Júnior, propõe interessante via a espancar a questão. A inexistência de menção expressa, tanto no dispositivo adjetivo como no estatutário, quanto à responsabilidade atribuída ao juiz, induz à interpretação no sentido da responsabilidade direta do Estado (constitucional, portanto), com direito de regresso em face do Juiz. Respeitada a posição do notável jurista, porém, acredita-se que a via direta em face do EStado não deve ser obrigatória. ${ }^{+1}$

Mário Moacyr Porto ${ }^{42}$, procura compatibilizar a Constituição com o texto adjetivo, sustentando responsabilidade direta do Estado (portanto a inconstitucionalidade), nas hipóteses do inc. I; com a responsabilidade pessoal do juiz (portanto a constitucionalidade por se tratar de matéria correcional), nas hipóteses do inc. II. A discordância, contudo é de rigor, pois a regra do art. $37, \S 6^{\circ} \mathrm{da} C F$ é clara a incluir qualquer ato seja qual for a sua natureza. Não há, destarte, relevo nesta distinção.

Parte considerável da doutrina ${ }^{43}$, contudo, comunga da referida inconstitucionalidade, ao aceitar tão-somente a hipótese da responsabilidade direta e objetiva do Estado.

Há que se entender o contrário, maxima permissa vênia, pelos seguintes argumentos.

Caso se entenda que a regra do art. 133 do CPC constitui exceção inafastável à regra geral da responsabilização direta do art. $37, \S 6^{\circ}$ e $5^{\circ}, \mathrm{LXXV}$. da Constituição de 1988, a inconstitucionalidade será de manifesta evidência.

41 Cabe a transcrição de parte de sua argumentação, "Para solver o impasse, é preciso considerar, em primeiro lugar, que tanto o Código de Processo Civil como a Lei Orgânica da Magistratura nada referem quanto à imediatidade da responsabilidade atribuída do Juiz, pelo que se deve interpretar tais regras em consonância com o texto constitucional, isto é, o Estado responde primária e diretamente frente ao lesado; o Juiz responde regressivamente. frente a Estado, nos casos figurados no art. 133. para a jurisdição civil, e no art. 49 da LOMAN, para as demais jurisdições. Isso significa respeitar o princípio geral da responsabilidade direta do Estado pelos atos dos seus agentes, $\mathrm{c}$ a limitação do direito de regresso, $\mathrm{cm}$ se tratando de ato judicial, às hipóeses dos artigos mencionados" (op. cit., p. 32-33).

42 Op. cit., p. 563-9

43 Comungam da inconstitucionalidade, Juary Silva (op. cit., p. 215-220), Edmir Netto de Araújo (op. cit., p. 64), José Cretella Júnior, ao aceitarem tão-somente a hipótese da responsabilidade direta c objetivo do Estado. Para este último, “... é insustentável o disposto no art. 121 do CPC de 1939. principalmente depois da CF de 1946. Pessoalmente o juiz não é responsável. Nem pode ser Responsável é o Estado. Juiz é órgão do Estado. Estado e Juiz formam um todo indissociável. Se o magistrado causa dano ao particular, o Estado indeniza, exercendo depois o direito de regresso contra o causador do dano" (Responsabilidade do Estado por Atos Judiciais, RDA, 99/13). 
Em razão da sistemática adotada em nosso ordenamento, fundado em texto constitucional rígido (às vezes até mesmo imutável), a exceção à norma Constitucional somente poderá ser instituída por outra norma de índole constitucional (emenda constitucional por exemplo, e ainda com as limitações formais, temporais, circunstanciais e materiais impostas ao poder constituinte revisor), jamais por lei ordinária.

Caso se considere que a regra do art. 133 do CPC constitui complemento, ao oferecer ao lesado a via pessoal e direta ao juiz responsável pelo dano, sem the subtrair a via direta ao Estado, então, não haverá qualquer antinomia a ser dirimida, eis que o espírito do legislador deverá ser sempre interpretado em prol da melhor tutela oferecida àquele em benefício de quem o instituto foi construído.

Como o fez com o juiz, poderá fazê-lo com outras categorias prestadoras de serviço ou atividade pública, sem que isso implique na subtração à via direta, objetiva, solvente, do Estado, grande conquista do Estado Democrático de Direito (com eficácia ressarcidora, sancionatória e moralizadora), mas que, ao ser condenado, fará a vítima (já dilapidada) aguarar pelo efetivo pagamento por anos, quiçá por décadas.

Portanto, em face do juiz, diretamente, apenas podeká ser proposta a demanda sob o fundamento da conduta dolosa e da fraude, em razão de sua responsabilidade pessoal, nunca da conduta culposa. Esta, poderá ser perquirida somente em sede regressiva (portanto indiretamente) a partir da condenação do Estado.

Em face do Estado, diretamente, poderá ser ajuizado o pleito indenizatório, a qualquer título e sob qualquer fundamento, desde que provado o nexo do dano (indenizável e injusto) com a atividade desenvolvida pelo Estado. Responderá o Estado, portanto, por conduta dolosa, culposa, mesmo falha anônimạa do serviço judiciário e até mesmo por ato lícito deste.

Assim, responde por dolo o juiz diretamente (sendo a responsabilidade do Estado subsidiária) ou o Estado diretamente (regredindo ao juiz) por escolha do interessado. Responde por culpa apenas o Estado diretamente (com regresso ao Juiz, após a condenação ou denunciando-o à lide). Responde por falha anônima ou por ato lícito apenas o Estado diretamente.

A coexistência de ambos os regimes, o da responsabilidade pessoal do juiz e da responsabilidade objetiva do Estado deve resultar em prol do usuário do serviço a quem caberá a escolha em face de quem demandar e a qual título. Há que se compartilhar, destarte, do entendimento esposado pela nova tendência que vem ganhando força entre nós, a partir de trabalhos recentemente defendidos e publicados, malgrado tenham seus autores optado pelo viés processual na abordagem do tema. ${ }^{44}$

Trata-se, portanto, de instituto protetivo da vítima e não restritivo de seu direito. 


\subsection{2 - Código de Processo Penal}

De todas as espécies de prestação judicial defeituosa consideradas em seu senido mais amplo, sem sombra de dúvidas, apresenta-se como a mais clamorosa injustiça e mais gritante aos auspícios do senso médio a do erro judicial criminal. A liberdade (e por certo a vida nos ordenamentos que adotam a pena capital) constitui o bem mais importante do indivíduo, constituindo a esfera nuclear de seus direitos e interesses indisponíveis a qualquer título.

A tutela deste precioso bem constitui a origem da reparação por erro judiciário em todos os tempos e em todos os ordenamentos.

Veja-se o caso brasileiro.

Da exegese do art. 630 do Código de Processo Penal ${ }^{45}$, dispositivo citado, cumpre detacar alguns pontos.

Primeiro, bastará a condenação equivocada ao ensejo da pretensão ressarcitória, inobstante não tendo havido prisão. Esta, ademais, certamente representará um plus não sendo, contudo, pressuposto da ação reparadora. ${ }^{46}$

Segundo, conforme consta, mister se faz a procedência da pretensão revisional a amparar o pedido ressarcitório. Neste caso, a desconstituição do julgado será condição sem a qual não haverá que se falar na ação civil. ${ }^{47}$

Terceiro, o comando do $\S 2^{\circ}$, letra $b$, representa injustificável e odiosa discriminação, tendo em vista a irrelevância da origem da ação penal, pois a decisão passível de causação do dano emerge do agente estatal e não do particular. Ademais,

45 Reza o art. 630 do Código de Processo Penal:

"O Tribunal, se o interessado o requerer, poderá reconhecer o direito a uma justa indenização pelos prejuízos sofridos.

$\$ 1^{\circ}$ - por essa indenização, que será liquidada no juízo civel, responderá a União, se a condenação tiver sido proferida pela Justiça do Distrito Federal ou de Território ou o Estado, se o tiver sido pela respectiva justiça.

$\$ 2^{\circ}$ - A indenizaçāo não será devida:

a) se o erro ou a injustiça da condenação proceder de ato ou falta imputável ao próprio impetrante. como a confíssão ou a ocultação de prova em seu poder;

b) se a acusação houver sido meramente privada".

46 A propósito o escólio de Soares Hentz, "Veja-se que a incidência da nova regra não depende de ter havido prisão, bastando a condenação errônea para ser postulada a reparação de danos materiais e morais porventura decorrentes da atividade judiciária" (op. cit., p. 62).

47 Comunga dessa posição Juary Silva, “... parece-nos que a desconstituição da sentença transitada em julgado seja pré-condição essencial no atinente à caracerização dessa responsabilidade. em todas as hipóteses em que ela decorrer de sentença de mérito" (op. cit., p. 174).

Em sentido contrário posiciona-se Soares Hentz, “A sustentaçāo que se faz aqui é no sentido da desnecessidade de desconstituir o julgado cível ou criminal, podendo a indenização ser postulada como ação autônoma, já que a coisa julgada não opera impedimento a considerações sobre eventual desacerto do julgamento" (op. cit., p. 43).

Há que se concordar com a última tese. Luvável, ademais, a posição assumida por Ruy Stoco, admitindo a necessidade da desconstituição do julgado como pré-condição submetendo-a, contudo, às hipóteses de decisão de mérito bem como restringindo seus efeitos às partes (Responsabilidade do Estado por erro judiciário, RBCCrim., n. 21/94-95). 
ao citar a ação meramente privada, incabível sua aplicação da exceção aos casos de ação privada subsidiária ou supletiva. ${ }^{48}$

Quarto, a pretensão ressarcitória ocorrerá como faculdade concedida à parte e não como obrigação do Estado, sendo processada e julgada no juízo cível. ${ }^{49}$

Quinto, a hipótese excludente de culpa do condenado não pode ser considerada a sério, sendo desnecessária a sua menção. A confissão pura e simples, sem estar corroborada pelas demais provas carreadas aos autos, já não goza mais da condição de "rainha das provas". Ademais, afrontaria o contraditório a exclusividade da prova. Caberia ao Estado, além disso, processar o indevidamente condenado pelo crime de auto-acusação falsa. Neste ponto, cabe destacar a hipótese de culpa concorrente da vítima com o Estado, devendo o julgador graduar a parcela de responsabilidade de cada um.

Sexto, não há, no dispositivo, qualquer menção a eventual direito de regresso por parte do Estado em face do julgador responsável pelo erro e, portanto pela condenação a ser satisfeita pela Fazenda.

Sétimo, não há qualquer alusão ao erro causado por anormal funcionamento da máquina, por erro advindo do trabalho dos colaboradores da justiça (perito, jurados, etc.), bem como da importante hipótese de ato jurisdicional lícito, ou seja, da prisão provisória seguida de decisão absolutória.

48 Lícito trazer à colação o ensinamento de Juary Silva, "A sentença condenatória, no entanto. não se torna privada, como consequêencia da titularidade privada da ação penal. Ela jamais perde seu caráter publicístico. Não é o querelante quem dita a sentença. mas sim o magistrado. de acordo com a sua conviç̧ão e a prova dos autos, fundamentando necessariamente suas conclusões. Essa fundamentação não pode cingir-se à palavra ou às alegações do querelante, porque a lei exige categoricamente "a indicação dos motivos de fato e de direito em que se fundar a decisão" ... "Logo, se erro houve na prolação de sentença em processo de ação meramente privada, será imputável ao aparato judiciário, e não ao querelante, devendo responder por isso o Estado, da mesmal forma que se a acusação tivesse sido pública" (op. cit., p. 194).

Esclarecedora a lição de Yussef Cahali, equalizando a bom termo a revogação do dispositivo surpacitado pelo comando posterior, superior e derrogador da Carta de 1988. A saber." ...essa ressalva já não mais prevalece diante da literalidade do art. $5^{\circ}, \mathrm{LXXV}$, da Constituição de 1988 , que não estabelece nenhuma distinção entre os processos criminais em que terá falhado a máquina judiciária na prestação jurisdicional.

"Aqui, a iniciativa da ação penal de que resultou a sentença condenatória desconstitutiva representa a causa remota do dano sofrido pelo ofendido; a causa imediata, eficiente e adequada. e que se sobrepõe àquela, é representada pelo erro judiciário na prolação da sentença condenatória.

"O que se pode admitir, apenas, é que, tendo a Justiça sido induzida em erro por fato imputável ao querelante, contra este caberia ação de regresso" (op. cit., p. 609).

49 Neste sentido. o magistério de Juary Silva. "O art. 630 do CPP prevê tal responsabilidade em caráter facultativo. não obrigatório, condicionando-a ainda ao pedido da parte. (...) A pretensão indenizatória fica assim entregue à apreciação do órgão de revisão, numa curiosa simbiose das jurisdições cível e penal. não se justificando, contudo, que a indenização dependa de pedido da parte. porquanto tecnicamente ela deveria ser construída como corolário do reconhecimento da inocência do condenado e diı falha do mecanismo judiciário. quando o declarou culpado, sem que o fosse" (op. cit., p. 191-192). 
$\mathrm{O}$ art. 621 do CPP dispõe de forma expressa ao elencar taxativamente as hipóteses de revisão criminal:

“A revisão dos processos findos será admitida: I - quando a sentença condenatória for contrária ao texto expresso da lei penal ou à evidência dos autos; II - quando a sentença condenatória se fundar em depoimentos, exames ou documentos comprovadamente falsos; III - quando, após a sentença, se descobrirem novas provas de inocência do condenado ou de circunstância que determine ou autorize diminuição especial da pena”.

Oitavo, o ressarcimento será o mais amplo possível, abrangendo "os prejuízos sofridos", podendo, na hipótese de falecimento da vítima, ser pleiteado pelos herdeiros.

Finalmente, ao confrontar o dispositivo adjetivo com o Constitucional (art. $5^{\circ}$, LXXV), percebe-se a amplificação, em boa hora, sofrida pelo aludido instituto, eis que o último alarga o enfoque, até então restritivo. dado à matéria, ao incluir, sob sua égide, as hipóteses de erro judiciário civil, de prisão indevida e, enfim sanando a obtusa redação, a ação penal privada. ${ }^{50}$

Destarte, prima o entendimento, ora predominante, de que o ressarcimento na esfera penal (que inclui também mas não apenas o dispositivo do art. 630 do CPP) abrange as seguintes hipóteses: prisão indevida sem condenação; condenação indevida sem prisão; e condenação indevida com prisão, sendo irrelevante a origem pública ou privada da ação penal.

A propósito, convém ressaltar a miopia do legislador, a propósito da disciplina do Código de Processo Penal que, embora abraçando a melhor doutrina, qual seja, a da responsabilidade objetiva, ainda deixa muito a desejar em termos de disciplina efetiva do instituto, restando o dispositivo extremamente limitativo da responsabilização pública por atividade judiciária penal danosa. ${ }^{51}$

Embora constitua entendimento ainda não pacificado, compreendende-se que o art. 630 do CPP, portanto, não foi ab-rogado pelo art. $5^{\circ}, \mathrm{LXXV}$ da CR, sendo amplificadas as hipóteses de incidência, podendo entrever, no $\S 2^{\circ}$, letra $b$, a derrogação do dispositivo, por incompatibilidade com o regime adotado pela Lei Maior.

Irretocável, a propósito, a observação de Rui Stoco ${ }^{52}$, "O erro judiciário traduz uma situação casuística e que, portanto, exige eu se analise caso a caso. Mais. Não

50 Uma vez mais, convém trazer à lume o sempre citado trabalho de Luiz Antonio Soares Hentz." ... o enfoque restritivo do art. 630 do Código de Processo Penal cedeu lugar para abarcar todas as hipóteses de erro judiciário e de prisão indevida, acabando com a discussão sobre a lógica da exclusão dos erros oriundos de ação penal privada e, por incondicionado o direito ora proclamado, independe da revisão criminal para sua postulação" (op. cit., p. 62).

51 A esse propósito assevera Juary C. Silva construída isoladamente, no interior de uma única codificação adjetiva, a teoria dessà responsabilidade não pôde senão amesquinhar-se, deixando de se alçar à magnitude que efetivamente comporta. Todo mecanismo judiciário bem idealizado precisa conter um submecanismo hábil à correção de seus desvios e erros, sem o que não pode alcançar bons índices de desempenho" (op. cit., p. 193).

52 Responsabilidade do esıado por erro judiciário, p. 91. 
se justifica nos dias atuais o estabelecimento de uma regra específica para o erro judiciário, tal como posto no art. 630 do CPP e no art. $5^{\circ}$ da Constituição Federal se já existe uma regra geral, ao nível constitucional, estabelecendo, a responsabilidade objetiva do Estado, por danos que seus agentes causarem a terceiros (CF, art. $37, \S 6^{\circ}$ ).

\subsection{3 - Código Civil de 1916}

A disciplina do Código Civil de 1916 sobre o tema está assim posta:

Art. 15: "As pessoas jurídicas de direito público são civilmente responsáveis por atos dos seus representantes que nessa qualidade causem danos a terceiros, procedendo de modo contrário ao direito ou faltando a dever prescrito por lei, salvo o direito regressivo conta os causadores do dano".

Já é consabido que este dispositivo inaugurou a responsabilidade objetiva e direta do Estado, ao contrário da previsão existente no direito positivo pátrio.

A expressão "representantes" utilizada deve ser estendida aos magistrados, já que o legislador não optou pela utilização do termo "funcionário".

A recusa de boa parte da doutrina e da maioria esmagadora da jurisprudência em aceitar tal comando deveu-se, em parte, à antinomia havida entre o diploma civilista e a Constituição então vigente, conforme ensina Edmir Netto de Araújo ${ }^{53}$ : "É claro que isso não era o que dispunha a Constituição então vigente, e provavelmente essa a razão da relutância do Poder Judiciário em aceitar a teoria objetiva da responsabilidade, que se lançava no panorama jurídico brasileiro. Iniciava-se, aqui, a lide jurisprudencial".

Outros dispositivos presentes no Código Civil de 1916 tratam da matéria de maneira específica ${ }^{54}$

53 Op. cit., p. 57.

54 Sāo os dispositivos que seguem:

Art. 294: "Ficará subsidiariamente responsável o Juiz que conceder a alienação fora dos casos e sem as formalidades do artigo antecedente, ou não providenciar a sub-rogação do preço e conformidade com o parágrafo único do mesmo artigo".

Art. 420: "O Juiz responde subsidiariamente pelos prejuizos que sofra o menor em caso de insolvência do tutor, de lhe não ter exigido a garantia legal, ou de o não haver removido, tanto que se tornou suspeito".

E em conjunto com:

Art. 421: "A responsabilidade será pessoal e direta, quando o Juiz não tiver nomeado tutor, ou quando a nomeação não houver sido oportuna".

(Neste caso, a responsabilidade do juiz será subsidiária, acrescente-se):

Art. 1.551: "Consideram-se ofensivos da liberdade pessoal: I - o cárcere privado; II - a prisão por queixa ou denúncia falsa e de má fé; III - a prisão ilegal".

Art. 1.552: "No caso do artigo antecedente, n. III, só a autoridade, que ordenou a prisão, é obrigada a ressarcir o dano".

(A responsabilidade pessoal do juiz, no preente caso, subsumirá à norma caso tenha ele sido a referida autoridade, acrescente-se). 
Em razão de sua origem quase secular, ineiste alusão à responsabilidade objetiva do Estado por atividade judiciária, bem como restrição à responsabilidade direta do juiz ao dolo (como ocorre com os textos posteriores), emanando um tratamento casuístico do instituto, exceção feita ao art. 15.

Convém trazer à lume as palavras de Ruy Rosado de Aguiar Júnior ${ }^{55}$,

"Já soam diferentes as regras do Código Civil, editadas ao tempo em que predominava a dutrina regaliana e ainda à sombra de nossa longa tradição, mantida pelas Ordenações, de responsabilidade direta do Juiz. Os preceitos de lei civil, não há como negar, batem de frente com o princípio da responsabilidade direta do Estado, pois expressamente assinam ao Juiz a responsabilidade principal (art. 421), única (art. 1.552) ou subsidiária (arts. $294 \mathrm{e}$ 420). Nessa parte, deve, ser considerados revogados a partir da Constituição de 1946. Valem, porém, como referencial legal para a responsabilidade regressiva".

Acrescenta-se, por oportuno, o entendimento que tais dispositivos estariam já revogados pelo Código de Processo Civil de 1939 (art. 121), posterior, do mesmo grau hierárquico, genérico (alterando todo o contexto), eis que este passou a regular de modo genérico a responsabilidade do juiz em caso de dolo e culpa.

Parte da doutrina ${ }^{56}$ vai além na discussão da natureza antinômica dos dispositivos do Diploma Civil de 1916, invocando-a em suas entranhas.

“Assim, os arts. 294, 420 e 421 do Código Civil, que falam da responsabilidade pessoal do juiz, não têm cabimento dentro da própria sistemática do estatuto substantivo, porque se chocam com o art. 15 da lei material, que fala em representante. Como, então, a não ser em caso de dolo ou culpa, ser responsabilizado pessoalmente?".

\subsection{4 - Código de Processo Civil}

A hipótese de anulação da sentença em ação rescisória, faz emergir o direito ao ressarcimento, às hipóteses de sentença proferida em arrepio aos incs. I e II do art. 485 do CPC, a saber, por erro, prevaricação, concussão, corrupção, impedimento ou suspeição do magistrado ${ }^{57}$.

55 Op. cit., p. 33.

56 Mário Moacyr Porto, Responsabilidade civil do Estado. Atos legislativos e atos judiciais, p. 132.

57 Reza o art. 485 do CPC. "A sentença de mérito, transitada em julgado, pode ser rescindida quando:

I - se verificar que foi dada por prevaricação, concussão ou corrupção do juiz;

II - proferida por juiz impedido ou absolutamente incompetente...

$\$ 1^{\circ}$ - Há erro, quando a sentença admitir um fato inexistente, ou quando considerar inexistente um fato efetivamente ocorrido". 
Sobreleva, em importância e complexidade, a discussão de outro dispositivo do diploma adjetivo pátrio.

A lei adjetiva civil prevê a responsabilidade subjetiva do juiz à hipótese de dolo e fraude, bem como de denegação de justiça, sendo esta última virtualmente inverossímel, restando como letra morta em nosso ordenamento.

A disposição do art. 133 do Código de Processo Civil de $1973^{58}$, reproduz, como já visto o art. 121 da lei adjetiva de 1939.

Controvertido o dispositivo, mormente se interpretado em face da disposição constitucional vigente, aliás, desde a Carta de 1946 (art. 194).

Da leitura do artigo supracitado deduz-se, à primeira vista e àquela época (pois inexistia, em 1939, previsão constitucional hábil a amparar a responsabilidade pública objetiva), a irresponsabilidade, seja do Estado, seja do juiz. por erros judiciários não penais. A inovação trazida pelo Código de Processo de 1939 estatui a responsabilidade pessoal do juiz e não do Estado.

O mesmo texto (inspirado no art. 55 do Código de Processo Civil da Itália), pode ser encontrado no Código de Processo Civil atual, bem como sua reafirmação pela Lei Complementar n. 35, de 14.3.1979 (Lei Orgânica da Magistratura Nacional), em seu art. 49, com teor praticamente idêntico.

Quanto ao seu alcance, à sua abrangência, ponderar-se o que segue.

Cabível o entendimento de que a responsabilidade pessoal, prevista no art. 133 , não afasta a responsabilidade do Estado, ao contrário a complementa. A disciplina da lei processual versa sobre a casuística de atos praticados pelo juiz (ou não) revestidos de maior gravidade. Este é o entendimento do seu inciso I ao dispor sobre a fraude ou dolo, bem como as hipóteses de comportamento omissivo do inciso II. Ambas configuram crimes funcionais graves e não meras falhas anônimas ou culposas ocorridas no desempenho da atividade.

Nos demais casos, qual seja, da conduta culposa, do ato danoso lícito e da falha anônima, vale a disciplina genérica da responsabilidade estatal, direta e objetiva. Ademais, a matéria de responsabilidade pública é estranha à codificação adjetiva civil (que de maneira alguma poderia tratar a matéria), somente podendo ser disciplinada pela Constituição, ou, quando muito, em Lei Orgânica. ${ }^{59}$.

$58 \mathrm{CPC}$, art. 133, in verbis:

"Responderá por perdas e danos o juiz, quando:

I - no exercício de suas funções, proceder com dolo ou fraude;

II - recusar, omitir ou retardar, sem justo motivo, providência que deva ordenar de ofício, ou a requerimento da parte

Parágrafo único. Reputar-se-ão verificadas as hipóteses previstas no $\mathrm{n}$. II só depois que a parte. por intermédio do escrivão, requerer ao juiz que determine a providência e este não lhe atender o pedido dentro de dez (10) dias".

59 Juary Silva confirma esta posição, "... a matéria da responsabilidade do Estado por atos judiciais refoge da codificação adjetiva civil; seu lugar próprio é na Constituição, caso não seja numa Lei sobre a Jurisdição, tal como a possui a Alemanha (Gerichtsverfassungsgesetz), ou acaso numa Lei Orgânica sobre a Magistratura. Logo, não há estranhar a omissão do Código de Processo Civil no pormenor, o estranhável seria exatamente que este se pronunciasse a respeito" (op. cit., p. 214). 
Resta afirmar, nesta sede, qual seria a previsão legal aplicável à hipótese da responsabilização por dano provocado por ato doloso do juiz, justamente o ponto de intersecção das diferentes previsões legais.

Entende-se que o ajuizamento da ação, diretamente em face do juiz, tendo por fundamento sua responsabilidade pessoal, ou, ao contrário (e porque não simultaneamente), a propositura da demanda em face do Estado, em razão de sua responsabilidade objetiva (com possibilidade de regresso em face do juiz causador do dano), será faculdade a ser exercida exclusivamente pela vítima, conforme sua conveniên$\operatorname{cia}^{60}$.

Discute-se, agora, sua eficácia.

A propósito, lícito aduzir o entendimento de Juary C. Silva ${ }^{61}$ :

"O dispositivo estabelece, realmente, a responsabilidade pessoal do juiz, porém o faz de modo casuístico, só abrangendo hipóteses de exercício anormal da jurisdição, não as falhas comuns do serviço judiciário. De feito, configuram crimes ou falhas funcionais gravíssimas as hipóteses enunciadas no texto: procedimento com dolo ou fraude; recusa, omissão ou retardo de providência. Mas, na verdade, esse preceito não erige responsabilidade nenhuma, antes pelo contrário, a dificulta, ao restringi-la, bem como ao vinculá-la a medidas a serem tomadas pelo escrivão, no caso do inc. II".

Quanto à sua eficácia, irreal a disposição em tela, tendo em vista que ninguém desconhece os problemas de ordem prática advindos ao advogado que se indispõe contra o cartorário. Que dizer daquele que indispõe contra o juiz, se mormente sob a alegação de dolo ou fraude deste. em uma pequena cidade de primeira ou segunda entrâncias. ${ }^{62}$

Outra disposição, que empresta feição surrealista ao texto, é aquela contida em seu parágrafo único, a inviabilizar por completo a eficácia eventualmente pretendida pelo legislador.

60 ". A responsabilidade objetiva do Estado pelos prejuizos causados por seus agentes não afasta o direito que tem o prejudicado de postular a necessária reparação diretamente do funcionário que causou o dano". TJSP, AC 48.751-4, 15.09.98, Rel. Maurício Vidigal, designado.

61 Idem, p. 210-211.

62 O dispositivo, portanto, não passa do que Juary Silva denomina de "utopia jurídica” , conforme os trechos seguintes:

.... não é de boa política advocatícia impugnar um ato judicial sob o fundamento de má conduta do magistrado que o prolatou. Se ninguém gosta que se lhe apontem erros. muito menos que se lhe impute ato doloso ou fraudatório.

Ainda mais porque evidentemente o advogado não terá os olhos voltados apenas para aquela causa onde ocorreu o ato judicial de má fé, senão também para as outras, dependentes do mesmo juiz, inclusive as futuras.

“... e o advogado que suscitar problemas desse tipo muito provavelmente não ficará bem visto, quer perante a magistratura, quer no seio de sua própria classe” (Idem, p. 211-212). 
Ora, é consabido que o escrivão é funcionário que goza de estreita proximidade profissional do juiz, e até pessoal nas Comarcas de menor porte, sendo, portanto, pessoa de sua confiança. Risível imaginar-se, na prática, a cientificação do escrivão ao seu superior, sob as penas da lei. ${ }^{63}$

A justificativa à redação tão distanciada da realidade, talvez, pode ser encontrada na explicação trazida à colação pelo insigne Pontes de Miranda ${ }^{64}$, ao comentar o dispositivo. "De certo tempo a esta parte, operou-se em alguns paises a transformação econômica dos escrivães e tabeliães em pessoas de classe economicamente superior ao juiz". De qualquer forma, ainda nos dias de hoje não existe distância social entre os dois, a superioridade hierárquica é inconteste e as consequências de tão "atrevida" atitude dispensam maiores comentários.

Quanto à antinomia do dispositivo em tela, bem como do art. 49 da Lomandada a identidade de conteúdo, em relação ao texto constitucional (com a qual se deve comungar) diverge a doutrina acerca da compatibilidade do texto adjetivo com o comando emergente da Constituição.

Outros dispositivos da lei adjetiva aludem à responsabilidade do juiz, seja em relação à restituição de despesas indevidamente suporadas pela parte (art. 29), ou em razão do descumprimento dos prazos previstos em lei (arts. 189, 190, 193, 198 e 199$)^{65}$

63 Ainda, com sua habitual lucidez, Juary Silva, "O ponto nodal do preceito reside no parágrafo único do artigo, que subordina a configuração de qualquer das hipóteses do inc. II a requerimento especial da parte para tanto, por intermédio do escrivão, o qual, como ninguém ignora, é subordinado ao juiz, para fins disciplinares e administrativos. Ter-se-á, então, o inferior cientificando o superior para que este cumpra a lei, sob pena de responder civilmente!".

E arremata, "Evidentemente este dispositivo nāo passa de uma inanidade, tal o seu distanciamento, não só da vida juridica, mas até da vida social e das normas, a maioria não escritas. que a regem" (idem. ibidem).

64 Comentários ao Código de Processo Civil. t.2, p. 397.

65 Art. 29: “'As despesas dos atos, que forem adiados ou tiverem de repetir-se, ficarão a cargo da parte, do serventuário, do órgão do Ministério Público ou do juiz que, sem justo motivo, houver dado causa ao adiamento ou à repetição".

Art. 189: "O juiz proferirá:

I - os despachos de expediente, no prazo de 2(dois) dias:

II - as decisões, no prazo de 10 (dez) dias".

Art. 190: "Incumbirá ao serventuário remeter os autos conclusos no prazo de 24 (vinte e quatro) horas e executar os atos processuais no prazo de 48 (quarenta e oito) horas".

Art. 193: "Compete ao juiz verificar se o serventuário excedeu, sem motivo legítimo, os prazos que este Código estabelece".

Art. 198: "Qualquer das partes ou o órgão do Ministério Público poderá representar ao Presidente do Tribunal de Justiça contra o juiz que excedeu os prazos previstos em lei. Distribuída a representação ao órgão competente, instaurar-se-á procedimento para apuração de responsabilidade. $O$ relator. conforme as circunstâncias, poderá avocar os autos em que ocorreu excesso de prazo. designando outro juiz para decidir a causa".

Art. 199: "A disposição do artigo anterior aplicar-se-á aos tribunais superiores, na forma que dispuser o seu regimento interno". 


\subsection{5 - Lei Orgânica da Magistratura Nacional}

Dispõe o art. 49 da Lei Orgânica da Magistratura Nacional (Lei Complementrar n. 35 , de 14.3.1979:

"Responderá por perdas e danos o magistrado, quando:

I - no exercício de suas funções, proceder com dolo ou fraude;

II - recusar, omitir ou retardar, sem justo motivo, providência que deva ordenar de ofício, ou a requerimento das partes.

Parágrafo único. Reputar-se-ão verificadas as hipóteses previstas no n. II somente depois que a parte, por intermédio do escrivão, requerer ao magistrado que determine a providência e este não the atender o pedido dentro de $\operatorname{dez}(10)$ dias".

Note-se, primeiramente, que o legislador nada mais fez do que reproduzir o texto do diploma formal de 1939, reproduzido em 1973. Reforça-se, assim. no plano disciplinar e corporativo, a disciplina da codificação processual.

Ademais, percebe-se a ampliação das hipóteses de incidência do aludido dispositivo às demais searas jurídicas, incluindo, entre outros, o erro judiciário penal.

Por oportuno, cumpre ressaltar que o mesmo raciocínio hábil na verificação da inconstitucionalidade do art. 133 do $\mathrm{CPC}$, serve de embasamento à propalada inconstitucionalidade do art. 49 da Loman, em razão da identidade de comandos.

Malgrado sua natureza de lei complementar, a diferença a ser encontrada reside apenas no modo formal do quórum exigido, observadas as demais características das leis ordinárias, não havendo qualquer possibilidade de confronto com os comandos emergentes da Lei Maior.

A hipótese do art. 56, III, da Loman ${ }^{66}$, da insuficiente capacitação para o desempenho da função, espécie de imperícia, haverá que ensejar a responsabilidade direta do Estado, do mesmo modo que qualquer outra falha de autoria identificável ou não. A aferição da culpa em seus diversos graus, somente interessará a embasar eventual regresso do Estado contra o causador do dano.

\section{3 - Conclusões}

Cumpe salientar a notável discrepância existente quanto à abordagem do instituto pelos doutrinadores, invariavelmente conflitantes, e sua interpretação jurispru-

66 É a redação do art. 56 da Loman, tacitamente revogado pela Constituição Federal que não incluiu o Conselho Nacional da Magistratura em sua estrutura.

Art. 56: "O Conselho Nacional da Magistratura poderá determinar a aposentadoria, com vencimento proporcionais ao tempo de serviço, do Magistrado:

I - manifestamente negligente no cumprimento dos deveres do cargo;

II - de procedimento incompativel com a dignidade, a honra e o decoro de suas funções;

III - de escassa ou insuficiente capacidade de trabalho, ou cujo proceder funcional seja incompatível com o bom desempenho das atividades do Poder Judiciário" 
dencial pedominantemente reflatária à responsabilização pretendida, não se obtendo adequado equacionamento do cipoal de textos relativos à matéria.

O caminho perseguido para a construção do Estado Democrático de Direito passa, sem dúvida, por plena responsabilização em relação a danos causados por ato ou omissão de seus agentes, falta do serviço ou mau funcionamento deste. Partindo da unidade da soberania, cuja titularidade pertence ao povo, tripartida em funções distintas, eis que o poder é uno, decorre. por conseqüência lógica, a unidade de sua responsabilidade, sendo irrelevante se o ato lesivo perpetrado resultou de atividade do Executivo. Legislativo ou Judiciário. A doutrina e jurisprudência contemporâneas caminham para tal propósito.

Sob a égide da atividade judiciária inadequada colocam-se, portanto, os atos jurisdicionais típicos (sentenças e decisões interlocutórias emanadas de juízos monocrático ou colegiado); as denominadas atividades correcionais (cartórios judiciais e extrajudiciais, setores de inquérito policiais, estabelecimentos prisionais); as atividades desempenhadas no exercício do juízo eleitoral; os atos judiciais gerais e administrativos (como diretor de fórum ou secretaria); a demora excessiva na prestação jurisdicional, culposa ou não; a falha da máquina; a responsabilização por ato lícito porém especial e anomalamente danoso.

A previsão da responsabilidade pública como regramento constitucional surge nas constituições deste século, notadamente nas de 1934 e 1946. A Carta atual consolida a disciplina do instituto em seu art. $37, \S 6^{\circ}$ : amplia o alcance do texto em relação ao responsável pela causação do dano (pessoa jurídica de direito público, pessoa jurídica de direito privado prestadora de serviço público); estende a conceituação de funcionário à de agente (o que inclui todos aqueles que praticam atos a serviço do Estado); prevê o exercício, pelo Estado, do direito ou da ação regressiva àquele subjetivamente responsável pelo dano experimentado pelo particular (compatibilizando as teorias objetiva - Estado/vítima - e subjetiva - Estado/agente, o que já ocorria na Carta de 1967).

$\mathrm{O}$ acesso à prestação jurisdicional constitui direito fundamental amparado no art. $5^{\circ}, \mathrm{XXXV}$ da Constituição, ao assegurar a apreciação pelo Poder Judiciário de lesão ou ameaça a direito individual, difuso e coletivo. Tal dispositivo, contudo, vem sendo sistematicamente violado quando não ignorado pela defeituosa e ineficiente atividade judiciária desenvolvida no país. A excessiva demora na prestação jurisdicional acarreta, não raras vezes, danos irreparáveis aos usuários da atividade judiciária, caracterizando real denegação de justiça.

$\mathrm{O}$ direito brasileiro, a exemplo do estrangeiro, ainda hesita em estender à atividade do Poder Judiciário as conseqüências da responsabilização pública. A moderna doutrina e decisōes esparsas mitigam, é bem verdade. a tradicional irresponsabilidade da função jurisdicional, permanecendo, contudo, restrita às hipóteses do erro judiciário penal os casos de responsabilização. A aceitação da responsabilidade pública por atividade judicial encontra maiores restriçōes do que aquela relativa aos atos administrativos do Poder Executivo. A irresponsabilidade do Estado-juiz aparece não apenas como fase inicial mas presente até bem pouco tempo em inúmeros ordenamentos, fundada na soberania do Poder Judiciário, na independência do ma- 
gistrado, na inexistência de lei específica hábil a regular a matéria, na falibilidade contingencial dos juízes e, principalmente, na incontrastabilidade da coisa julgada.

A responsabilidade pessoal do juiz, de caráter individual, embora alheia ao específico objeto do presente trabalho, não lhé é estranha. Os diversos âmbitos de responsabilização do juiz, a saber político (distinguindo-se a responsabilidade do juiz enquanto indivíduo da magistratura como instituição, bem como a responsabilidade em face dos poderes políticos e responsabilidade constitucional; social (assumida perante o público em geral, podendo referir-se tanto ao juiz como indivíduo quanto ao Judiciário) e jurídico (que pode ser exclusiva ou concorrente com a responsabilidade pessoal do juiz, podendo esta última, ser penal, civil ou disciplinar) são instrumentos complementares da responsabilidade pública por atividade judiciária inadequada. Há que se ressaltar, contudo, que um único ato do juiz pode gerar todas essas espécies de responsabilidade.

A evolução histórica, traçada pelo direito brasileiro, tem origem em disposições específicas, surgindo já nas Ordenações do Reino, passando pelo Código de Processo Criminal de 1832 (arts. 129, 130 e 131); pelo Decreto n. 737/1850 (art. 677); Código Penal de 1890 (art. 165); Código Civil de 1916 (arts. 294. 420, 421, 1551 e 1552); Código de Processo Civil de 1939 (art. 121); Código Penal de 1940 (arts. 312, 313. 316. 317, 319.321 e 350); Código de Processo Penal de 1942 (art. 630); Lei n. 4.898 de 1965 (arts. $4^{\circ}$ e $6^{\circ}$ ); Código de Processo Civil de 1973 (arts. 133 e 485) e a Lei Complementar n. 35 de 1979 (arts. 49 e 56). Observe-se, a propósito, a curiosa omissão das Cartas Constitucionais, ressalva feita à de 1988 , em seu art. $5^{\circ}$, LXXV.

$\mathrm{O}$ direito positivo brasileiro contemporâneo aborda a disciplina do instituto de forma dispersa e por vezes antinômicas, a contar da nebulosa constitucionalidade do art. 133 do CPC, e do cipoal formado por dispositivos das lei adjetiva penal, da Lei Orgânica da Magistratura Nacional e mesmo do Código Civil, instituídos muito antes da previsão do art. $37, \S 6^{\circ}$ da Constituição, em face da qual os demais dispositivos devem ser confrontados.

Nesse diapasão, entende-se que o art. 133 do $C P C$, cuja disposição acha-se repetida na Loman, não se encontra eivado de inconstitucionalidade em face da Carta de 1988. A lei adjetiva civil prevê a responsabilidade subjetiva do Juiz na hipótese de dolo e fraude, bem como de denegação de justiça, sendo esta, da forma que se encontra prevista, virtualmente inverossímel, restando como letra morta em nosso ordenamento. $\mathrm{O}$ art. 485 prevê a rescisão do julgado como condição para o reconhecimento do erro judiciário, como seu requisito com o que não se há de concordar. Ademais, entendimentos outros aventam a viabilidade do pleito ressarcitório a despeito da desconstituição do julgado.

Resta indagar, nesta sede, qual seria a previsão legal aplicável à hipótese da responsabilização por dano provocado por ato doloso do juiz, justamente o ponto de intersecção das diferentes previsões legais.

Entende-se que o ajuizamento da ação diretamente em face do juiz, tendo por fundamento sua responsabilidade pessoal, ou, ao contrário (e porque não simultaneamente), a propositura da demanda em face do Estado, em razão de sua responsabilidade objetiva (com possibilidade de regresso em face do juiz causador do dano), será faculdade a ser exercida exclusivamente pela vítima, conforme sua conveniência 
(solvência da vítima, urgência no deslinde da questão, conjunto probatório que possibilite renunciar à inversão probatória propiciada em sede objetiva).

A conjugação de ambos os regimes, o da responsabilidade pessoal do juiz e o da responsabilidade objetiva do Estado, coexiste em prol do usuário da atividade a quem caberá a escolha em face de quem demandar e a qual título. Este o entendimento esposado pela nova tendência que vem ganhando força, a partir de trabalhos recentemente defendidos e publicados.

Caso se entenda que a regra do art. 133 do CPC constitui complemento, ao oferecer ao lesado a via pessoal e direta ao juiz responsável pelo dano (abdicando dos privilégios da solvência dos cofres públicos e da inversão do ônus da prova), sem lhe subtrair a via direta ao Estado, não haverá, então, qualquer antinomia a ser dirimida.

Os dispositivos da lei civil dispõem sobre situações específicas (arts. 294, 420 e 421 do Código Civil) de responsabilidade subjetiva do juiz, por negligência ou imprudência, restando eventual responsabilidade objetiva disciplinada, como regra geral, impropriamente pelo seu art. 15, inaplicável em face da Carta de 1988. Acrescenta-se, por oportuno, o entendimento que tais dispositivos estariam já revogados pelo Código de Processo Civil de 1939 (art. 121), posterior. do mesmo grau hierárquico. genérico (alterando todo o contexto), eis que este passou a regular de modo genérico a responsabilidade do juiz em caso de dolo e culpa.

A lei processual penal (art. 630 do $C P P$ ) disciplina expressamente a respeito do erro judiciário penal, confundido normalmente com seu gênero, porém condicionando ao alvedrio do interessado. As disposições constantes em seu $\S 2^{\circ}$. que o excluem nas hipóteses de culpa da vítima bem como da ação meramente privada encontram-se superadas, restando esta última verdadeira aberração jurídica.

Destarte, prima o entendimento ora predominante, que a indenização na esfera penal (que inclui também, mas não apenas, o dispositivo do art. 630 do CPP) abrange as seguintes hipóteses: prisão indevida sem condenação; condenação indevida sem prisão; e condenação indevida com prisão, sendo irrelevante a origem pública ou privada da ação penal.

$\mathrm{O}$ art. 630 do CPP, portanto, não foi ab-rogado pelo art. $5^{\circ}, L X X V$ da $C R$, sendo amplificadas as suas hipóteses de incidência, podendo entrever, quanto à hipótese $o$ $\S 2^{\circ}$ letra $b$, a sua derrogação.

As disposições da Constituição Federal, contidas em seu art. $5^{\circ}$, LXXV, tomam incondicional tal indenização, revogando o dispositivo restritivo e acrescentando a hipótese da prisão acima do tempo previsto.

A regra geral do art. $37, \S 6^{\circ}$ da Constituição de 1988 , abrange todas as demais hipóteses de maneira clara, bastando a constatação da existência de liame entre a conduta do agente (sob qualquer vínculo com a administração), lícita ou ilícita, e o dano injustamente sofrido pelo usuário da atividade judiciária.

O desenvolvimento regular da atividade judiciária deverá observar: a) o processo regular, de acordo com as exigências, prazos e formalidades legais; b) a legitimidade das partes e a competência legal do órgão judiciário; c) uma decisão de acordo com o direito vigente ou aplicável; d) uma decisão de pleno acordo com a prova dos autos, apurada na instrução processual. Não observados tais requisitos, 
ao usuário do serviço público da justiça será permitido demandar o poder público (ou o juiz) pelo desempenho defeituoso ou não desempenho da atividade de maneira adequada e eficiente.

Assim sendo, atos judiciais e jurisdicionais (do juiz, dos auxiliares, peritos, Ministério Público, jurados etc.) causadores de danos passíveis de reparação, falha da máquina, erro judiciário civil ou penal, demora excessiva na prestação jurisdicional, denegação de justiça, ato emanado de colegiado, atos causados pela Justiça Eleitoral, atos praticados em sede de tutela de urgência ou de execução ou mesmo atos lícitos são hábeis para ensejar a devida responsabilização pública, não apenas o chamado "erro judiciário".

À guisa de conclusão, lícito aduzir que a responsabilidade do Estdo por ato do Poder Judiciário não implica na restrição à soberania e independência de um Poder autônomo, ao contrário, só vem reforçar a independência do órgão julgador (assim como a responsabilidade da administração não implica em obstáculos ao desenvolvimento ou à boa administração da coisa pública, ao contrário, a garante), respeitadas as garantias pessoais de seus agentes bem como institutos que conferem segurança às relações jurídicas, a exemplo da coisa julgada. A relativização de dogmas, até então utilizados para justificar a irresponsabilidade do judiciário, portanto, encontra guarida no valor "justiça”, bem supremo a ser perseguido pela atividade jurisdicional.

A eficácia do sistema encontra seu limite na camisa de força em que se encontra o Judiciário. De um lado sobrevive à custa de um orçamento cada vez menor, repassado por um Executivo que não vê qualquer vantagem em sua eficiência; por outro, preso à legislação elaborada em tempos passados dependendo, portanto de produção legiferante a cargo de um Legislativo cooptado pelo Executivo. Culpado pela sua própria crise por ignorar sua existência, tem sua culpa mitigada por ser, dentre os Poderes, o que mais depende da atuação dos demais.

\section{Bibliografia}

AGUIAR JÚNIOR, Ruy Rosado de. A responsabilidade civil do Estado pelo exercício da função jurisdicional no Brasil. Revista da Associação dos Juízes do Rio Grande do Sul. Porto Alegre: AJURIS, n. 59, p. 5-48, nov. 1993.

. Responsabilidade política e social dos juizes nas democracias modernas. Revista dos Tribunais. São Paulo; Revista dos Tribunais, n. 751, p. 32-50, maio 1998.

ALESSI, Renato. La Responsabilitá della pubblica amministrazione. Milano: Giuffrè, 1955;

ARAÚJO, Edmir Netto. Responsabilidade do Estado por ato jurisdicional. São Paulo: Revista dos Tribunais, 1981.

ARDANT, Philippe. La responsabilité de l'Etat du fait de la fonction juridictionelle. Paris: LGDJ, 1956.

AROCA, Juan Montero. Responsabilidad civil del juez y del Estado por la actuacion del Poder Judicial. Madrid: Tecnos, 1988. 
BARROS, Octavio Augusto Machado de. Responsabilidade pública. São Paulo: Revista dos Tribunais, 1956.

BASTOS, Celso Ribeiro; MARTINS, Ives Gandra. Comentários à Constituição do Brasil. São Paulo: Saraiva, 1989;

BENOIT, Francis-Paul. Le droit administratif français. Paris: Dalloz, 1968.

BIELSA, Rafael. Principios de derecho administrativo, 3. Ed. Buenos Aires: Depalma, 1963. v. I.

. Derecho administrativo, 5. ed. Buenos Aires: Depalma, 1957. T. V.

Compendio de derecho administrativo. 2. ed. Buenos Aires: Depalma, 1957.

As vítimas dos erros judiciários nas causas criminais e o direito à reparação.

Revista Forense. Rio de Janeiro: Forense. n. 105. p. 482-486, jan. 1946.

BUZAID, Alfredo. Da responsabilidade do juiz. Revista de Processo. São Paulo, Revista dos Tribunais, n. 9, p. 15-36, jan./mar. 1978.

CAETANO, Marcello. Manual de direito administrativo. Rio de Janeiro: Forense, 1970. 2v.

CAHALI, Yussef Said. Responsabilidade civil do Estado. 2. ed. São Paulo: Malheiros, 1996.

CAPALOZZA, Enzo. Contributo allo studio dell'errore giudiziaro in materia penale. Padova: CEDAM, 1962.

CAPELLETTI, Mauro. Juizes irresponsáveis? Trad. de Carlos Alberto Álvaro de Oliveira. Porto Alegre: Sérgio Antonio Fabris Editor, 1989.

CARPI, Federico. A responsabilidade do juiz. Revista de Processo. São Paulo, Revista dos Tribunais, n. 78, p. 123-132, abr./jun. 1995.

CAVAlCANTI, Amaro. Responsabilidade civil do Estado. Rio de Janeiro Borsói/Laemmert, 1957. 2 v.

CAVALCANTI, Themístocles Brandão. Tratado de direito administrativo. Rio de Janeiro: Freitas Bastos, 1944. VI vol.

CHAPUS, René. Droit administratif général. Paris: Montchrestien, 1998.

CINTRA, Antonio Carlos de Araújo; GRINOVER, Ada Pellegrini;

DINAMARCO, Cândido Rangel. Teoria Geral do Processo. 15. ed. São Paulo: Malheiros, 1999;

COTRIM NETO, A. B. Da responsabilidade do Estado por atos do juiz em face da Constituição de 1988. Revista de Direito Público. São Paulo, Malheiros, n. l. p. 31-49, 1993.

COUTO E SILVA, Almiro. A responsabilidade extracontratual do Estado no direito brasileiro. Revista de Direito Administrativo. Rio de Janeiro, Renovar, n. 202, p.19-4l, out./dez. 1995.

CRETELLA JÚNIOR, José. Responsabilidade do Estado por atos judiciais. Revista Forense. Rio de Janeiro, Forense, n. 230, p. 37-46, abr./jun. 1970.

. Comentários à Constituição Brasileira de 1988. Rio de Janeiro. Forense Universitária, 1999. v. IV.

Manual de direito administrativo. 6. ed. Rio de Janeiro: Forense. 1992.

O Estado e a obrigação de indenizar. Rio de Janeiro: Forense. 1998.

Tratado de direito administrativo, Rio de Janeiro: Forense, 1972. v. VIII. 
CUSTÓDIO, Helita Barreira. Responsabilidade civil do Estado: princípios gerais. Revista de Direito civil, Imobiliário, Agrário e Empresarial. São Paulo, Revista dos Tribunais, n. 78, p. 55-103, out./dez. 1996.

DALLARI, Dalmo de Abreu. O poder dos juizes. São Paulo: Saraiva, 1996.

DELGADO, José Augusto. A demora na entrega da prestação jurisdicional. Responsabilidade do estado. Indenização. Revista Trimestral de Direito Público. São Paulo, Revista dos Tribunais, n. 14, p. 248-266, 1996.

DERGINT, Augusto do Amaral. Responsabilidade do Estado por atos judiciais. Revista dos Tribunais. São Paulo, Revista dos Tribunais, n. 710, p.225-230, dez. 1994.

. Responsabilidade do Estado por atos judiciais. São Paulo: Revista dos Tribunais, 1994.

DI PIETRO, Maria Sylvia Zanella. Responsabilidade do Estado por atos jurisdicionais. Revista de Direito Administrativo. Rio de Janeiro, Renovar, n. 198, p. 85-96, out./dez. 1994.

DINAMARCO, Cândido Rangel. Admissibilidade da denunciação da lide. Revista de Processo. São Paulo, Revista dos Tribunais, n. 85, p. 67-79.

DUEZ, Paul. La responsabilité de la puissance publique (em dehors du contraf). Paris: Dalloz, 1927.

DUGUIT, Léon. Traité de droit constitutionnel. 3. ed. Paris: Fontemoing, 1927. T. 3.

EISENMANN. Charles. Cours de droit administratif. Paris: LGDJ, 1983. 2 v. La justice dans l'Etat. pp. 11-56. In: "La justice". Presses Universitaires de France, 1961;

ESPÍNOLA FILHO, Eduardo. Codigo de Processo Penal Brasileiro, 9 v. Rio de Janeiro: Freitas Bastos/Borsói, 1944;

FARIA, José Eduardo. Direito e justiça. São Paulo: Ática, 1989; . (Coord.) A crise do direito numa sociedade en mudança. Brasília: UnB, 1988.

FIGUEIRA JÚNIOR, Joel Dias. Responsabilidade civil do estado-Juiz. Curitiba: Juruá, 1995.

FREDERICO MARQUES, José. Manual de direito processual civil, 4 v. Campinas: Bookseller, 1997;

GARCIA, Basileu. Instituições de direito penal, 2v. 4 ed. São Paulo: Max Limonad. 1978;

GRECO, Guido. La responsabilitá civile dell'amministracione e dei suoi agenti. In: Diritto amministrativo, 2. ed. [s.I.] Monduzzi Editore. [s.d.] v. II.

GRINOVER, Ada Pellegrini. A responsabilidade do juiz brasileiro. In: Estudos em homenagem a José Frederico Marques. São Paulo: Saraiva, 1982. p. 3-24.

GUIMARÃES, Mário. O juiz e a função jurisdicional. Rio de Janeiro: Forense, 1958. HENTZ, Luiz Antonio Soares. Indenização do erro judiciário. São Paulo: Livraria e Editora Universitária de Direito - LEUD, 1995.

. Responsabilidade do Estado por prisão indevida. Revista dos Tribunais. São Paulo, Revista dos Tribunais, n. 730, p. 68-79, ago. 1996.

LAFERRIĖRE, E. "Traité de la juridiction administrative et des recours contentieux", 2. ed. Paris-Nancy: Berger, 1896. T. 2. 
LASPRO, Oreste Nestor de Souza. A responsabilidade civil do juiz. São Paulo: Revista dos Tribunais, 2000.

LAUBADÈRE, André de. Traité élémentaire de droit administratif. 3v. 3. ed. Paris: LGDJ, 1963;

LEGUINA VILLA, Jesús. "El fundamento de la responsabilidad de la administración". Revista Española de Derecho Administrativo. [s.I.] p. 523-536, [1980];

"La esponsabilidade civil de la dministración publica". Madrid; Tecnos, 1970;

LENZ, Carlos Eduardo Thompson Flores. Responsabilidade do Estado por atos judiciais. Revista de Direito Administrativo. Rio de Janeiro: Renovar, n. 210: p. 147-158, out./dez. 1997;

LESSA., Pedro. Do Poder Judiciário: Direito constitucional. Rio de Janeiro: Francisco Alves, 1915.

LIMA. Hermes. Actividade administrativa do Estado. São Paulo: Livraria Acadêmica. 1927.

LOMBARD, Martine. La responsabilité du fait de la fonction juridictionelle et la loi du 5 juillet 1972. Revue du Droit Public e de la Science Politique en France et a l'Etranger. Paris, LGDJ, n. 3, p. 585-634, mai./ju. 1975.

MEDAUAR, Odete. Direito administrativo moderno. 4. ed. São Paulo: Revista dos Tribunais, 2000.

. O direito administrativo em evolução. São Paulo: Revista dos Tribunais, 1992. Serviço público. Revista de Direito Administrativo. Rio de Janeiro: Renovar, n. 189: p. 106-113, jul./set. 1997.

MEIRELLES, Hely Lopes. Direito administrativo brasileiro. 24. ed. São Paulo: Malheiros, 1999.

MORAES, Nélson Teixeira de Barros. Da responsabilidade civil do Estado na ação rescisória de julgado. Justitia. São Paulo: Procuradoria Geral da Justiça, n. 72: p. 75-78, 1 trim. 1971;

MOURÃO, Jacira Nunes. Responsabilidade civil do estado por atos jurisdicionais. Revista de Direito Civil, mobiliário, Agrário e Empresarial. São Paulo, Revista dos Tribunais, n. 3, p. 65-84, jan./mar. 1978.

NANNI, Giovanni Ettore. A responsabilidade civil do juiz. São Paulo: Max Limonad, 1999.

NUNES, Rómulo José Ferreira. Responsabilidade do Estado por atos jurisdicionais. São Paulo: LTr, 1999.

OLIVEIRA. Fernando Andrade. Apontamentos sobre a responsabilidade patrimonial do Estado administrador. In: MELLO, Celson Antonio Bandeira de (Org.) Estudos em homenagem a Geraldo Ataliba. São Paulo: Malheiros, p. 360-402.

OLIVEIRA, Paulo Aguiar. Responsabilidade do Estado por atos da Justiça Eleitoral. Revista de Direito Público. São Paulo, Malheiros, n. 83, p. 61/67, jul./set. 1997.

PAILLET, Michel. La responsabilité administrative. Paris: Dalloz, 1996.

PONDÉ, Lafayette. Da responsabilidade civil do Estado por atos do Ministério Público. Revista Forense. Rio de Janeiro, Forense, n. 152, p. 43-51, mar./abr. 1954.

PONTES DE MIRANDA, Francisco Cavalcanti. Comentários ao Código de Processo Civil, Rio de Janeiro: Forense, 1975. 17 v. 
Comentários à Constituição da República dos Estados Unidos do Brasil. Rio de Janeiro: Guanabara, 1936. T. II.

PORTO, Mário Moacyr. Responsabilidade civil do Estado. Atos legislativos e atos judiciais. Revista Forense. Rio de Janeiro, Forense, n. 329, p. 131-134. jan./mr. 1995.

. Responsabilidade do Estado pelos atos de seus juizes. Revita dos Tribunais. São Paulo, Revista dos Tribunais, n. 563, p. 9-14, set. 1982.

REBOLLO, Luiz Martin. La responsabilidad patrimonial de la administración en el panorama europeo. Revista Espanhola de Derecho Administrativo. (s.I.] . 17-28, [1980].

SALAZAR, Alcino de Paula. Responsabilidade do poder público por atos judiciais. Rio de Janeiro: Canton \& Reile, 1941.

SANTOS, Moacyr Amaral. Primeiras linhas de direito processual civil, 15. ed. São Paulo: Saraiva, 1995. v. 3.

SAVATIER, René. Du droit civil au droit public. Paris: LGDJ, 1950.

SCHIESARI, Nelson. Da responsabilidade civil do Estado e seus limites. Dissertação de Mestrado. São Paulo:Faculdade de Direito da Universidade de São Paulo, 1980, $176 \mathrm{p}$

SÉ, João Sento. Responsabilidade civil do Estado-juiz. Revista de Direito Público. São Paulo, Revista dos Tribunais, n. 82, p. 132-140, jan./mar. 1987.

. Responsabilidade civil do Estado por atos judiciais. São Paulo: José Bushatsky Editor, 1976.

SILVA, Juary C. A responsabilidade do Estado por atos judiciários e legislativos. São Paulo. Saraiva, 1985.

- Responsabilidade civil do Estado por atos jurisdicionais. Revista dos Tribunais. São Paulo: Revista dos Tribunais, n. 351, p. 19-50, jan. 1965.

SILVA FILHO, Artur Marques da. Juizes irresponsáveis? uma indagação pesente. Revista dos Tribunais. São Paulo, Revista dos Tribunais, n. 674, p. 70-80, dez. 1991.

SORACE, Domenico. La responsabilità pubbliche civile, amministrativa, disciplinare, penale, dirigenziale. Milani: CEDAM, 1998;

SOUZA, José Guilherme de. A responsabilidade civil do Estado pelo exercício da atividade judiciária. Revista dos Tribunais. São Pualo: Revista dos Tribunais, n. 652: p. 29-49, fev. 1990.

STOCO, Rui. Responsabilidade civil e sua interpretação jurisprudencial. 4. ed. São Paulo: Revista dos Tribunais, 1999.

. Responsabilidade do Estado por erro judiciário. Revista Brasileira de Ciências

Criminais. SãoPaulo, Revista dos Tribunais, n. 21, p. 91-101, jan./mar. 1998.

TOURINHO FILHO, Fernando da Costa. Código de Processo Penal comentado. $2 \mathrm{v}$. $19^{a}$ ed. São Paulo: Saraiva, 1997;

TRUJILLO, Elcio. Responsabilidade do Estado por ato lícito. Leme: Editora de Direito - LED, 1996.

VINCENT, Jean; MONTAGNIER, Gabriel; VARINARD, Andre. La justice et ses institutions. Paris: Dalloz, 1982.

WALINE, Marcel. Droit administratif. 9. ed. Paris: Sirey, 1963; 
Traite elémentaire de droit administratif. 6. ed. Paris: Sirey, 1952;

ZAFFARONI, Eugenio Raúl. Poder Judiciário. Crise. Acertos e desacertos. São Paulo: Revista dos Tribunais, 1995;

ZANCANER, Weida. Da responsabilidade extracontratual da Administração Plíblica. São Paulo: Revista dos Tribunais, 1981;

ZANOBINI, Guido. "Corso di diritto amministrativo". 6 v. $7^{\mathrm{a}}$ ed. Milano; Giuffrè. 1954. 